ANTÔNIO SCALCO FABRIS

\title{
ANÁLISE BACTERIOLÓGICA DE INFECÇÕES PULPARES EM DENTES DECÍDUOS
}

Tese apresentada ao Programa de PósGraduação em Microbiologia do Instituto de Ciências Biomédicas da Universidade de São Paulo, para obtenção do Título de Doutor em Ciências. 
ANTÔNIO SCALCO FABRIS

\section{ANÁLISE BACTERIOLÓGICA DE INFECÇÕES PULPARES EM DENTES DECÍDUOS}

Tese apresentada ao Programa de PósGraduação em Microbiologia do Instituto de Ciências Biomédicas da Universidade de São Paulo, para obtenção do Título de Doutor em Ciências.

Área de concentração: Microbiologia.

Orientador: Prof. Dr. Mario Julio AvilaCampos. 
DADOS DE CATALOGAÇÃO NA PUBLICAÇÃO (CIP)

Serviço de Biblioteca e Informação Biomédica do

Instituto de Ciências Biomédicas da Universidade de São Paulo

(C) reprodução total

Fabris, Antônio Scalco.

Análise bacteriológica de infecções pulpares em dentes decíduos / Antônio Scalco Fabris. -- São Paulo, 2011.

Orientador: Mario Julio Avila-Campos.

Tese (Doutorado) - Universidade de São Paulo. Instituto de Ciências Biomédicas. Departamento de Microbiologia. Área de concentração: Microbiologia. Linha de pesquisa: Microbiologia oral e anaeróbios.

Versão do título para o inglês: Bacteriological analysis of pulp infection in deciduous teeth.

Descritores: 1. Dente decíduo 2. Infecções pulpares 3. Reação e cadeia por polimerase (PCR) I. Avila-Campos, Mario Julio II. Universidade de São Paulo. Instituto de Ciências Biomédicas. Progrma de Pós-Graduação em Microbilogia III. Título. 


\section{UNIVERSIDADE DE SÃO PAULO \\ INSTITUTO DE CIÊNCIAS BIOMÉDICAS}

Candidato(a): $\quad$ Antônio Scalco Fabris.

Título da Tese: Análise bacteriológica de infecções pulpares em dentes decíduos.

Orientador(a): $\quad$ Mario Julio Avila-Campos.

A Comissão Julgadora dos trabalhos de Defesa da Tese de Doutorado, em sessão pública realizada a considerou
( ) Aprovado(a)
( ) Reprovado(a)

Examinador(a): Assinatura:.

Nome:

Instituição:

Examinador(a): Assinatura:

Nome:

Instituição:

Examinador(a): Assinatura:

Nome:

Instituição:

Examinador(a): Assinatura:

Nome:

Instituição:

Presidente: Assinatura:

Nome:

Instituição: 


\section{PARECER 678/CEP}

São Paulo, 17 de novembro de 2005.

Prezado Senhor,

Atendendo sua solicitação a Conissão de Êtica em Pesquisas com Seres Humanos do $/ C B$, em sua $60^{\circ}$ reuniao, realizada no dia 16 de novembro de 2005 , analisou o projeto de sua responsabilidade intitulado: "Análise molecular de microorganismos presentes nas infecçốes endodónticas de dentes deciduos".

Informo a V.Sa. que, após análise as respostas das questōes levantadas por esta comissão, o referido projeto foi aprovado.

Esclareşo a V.Sa. que dentro de 12 meses, relatório do referido projeto deverá ser encaminhado à Secretaria deste CEP.

\section{Atenciosamente,

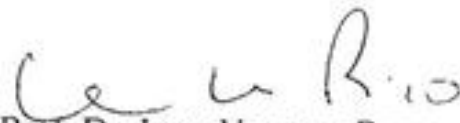 \\ Prof. Dr. LUIZ VICENTE RIZZO}

Coordenador da Comissāo de Ética em

Pesquisas com Seres Humanos - ICB /USP

IImo. Sr.

ANTONIOSCALCO FABRIS

Departamento de Microbiologia

Instituto de Ciências Biomédicas -USP

Comissão de Ética em Pesquisa com Seres Humanos do Instituto de Ciênclas Błomédicas / USP Aprovada pela Comissaio Nacional de Ética em Pesquisa - CONEP. em 10 de fevereiro de 1998. 
Tos meuspais, Daiton e Milaria

do Tarmo (in memoriam).

Ttminha querida esposa Myriam,

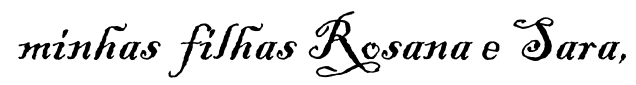
meus irmãos M̆́rcía e Losé

Iuiz (in memoriam).

Obrigado! 


\section{AGRADECIMENTOS}

A Deus que tornou possível a realização desta tese, um Amigo em todos os momentos.

Agradeço especialmente ao meu orientador, Prof. Dr. Mario Julio AvilaCampos, pelos conhecimentos transmitidos com dedicação, paciência, simplicidade, incentivo e confiança. Ao senhor, toda minha amizade e respeito.

A todos os meus professores do Curso de Pós-Graduação em Microbiologia, pelas excelentes aulas e ensinamentos recebidos.

Aos colegas do Laboratório de Anaeróbios, Elerson, Alfredo, Rafael, Luiz, Gerusa, Thais, Viviane Rodrigues e Viviane Nakano, obrigado pelas ideias e incentivos diários.

À Zulmira Alves pelo apoio técnico, ajuda e amizade.

Aos secretários do Departamento de Microbiologia, Alice Shimabuku, Ana Maria Amaral, Naide Farripas, e da Pós-Graduação Celso Pereira e Luciana da Silva, pela atenção e qualidade com que sempre me atenderam.

Aos funcionários da Biblioteca do ICB pela eficiência e simpatia no atendimento.

À Secretaria Municipal de Saúde de Vitória, ES, e Coordenação de Saúde Bucal pela aprovação da pesquisa.

Aos docentes do setor de Microbiologia da Universidade Federal do Espírito Santo, Prof. Dr. Gercyr Baptista, Prof ${ }^{a}$ Dra. Sônia Kitagawa, Prof ${ }^{a}$ Dra. Marícele Araújo Ribeiro, Prof ${ }^{a}$ Dra. Liliana Cruz Spano, e a todos os meus ex-alunos pelo incentivo, orientação e apoio.

À Paróquia Nossa Senhora das Graças da Arquidiocese de Vitória, ES. Aos Padres Dário Ferreira da Silva e Gustavo Corrêa Cola pelo apoio, compreensão e amizade. Também, à Pastoral da Criança e sua coordenadora, Sra. Glorinha Penha Seixas e equipe. 
À Escola Diaconal São Lourenço da Arquidiocese de Vitória, ES, e a seu diretor Prof. Pe. Arlindo Moura de Melo e equipe, pelos cursos ministrados. Aos meus colegas de curso de Teologia, pelo companheirismo, união, amizade e, sobretudo, ao Prof. Pe. Mukabi Misik Senga Pierre pelas aulas de Metodologia Científica.

À Obra Social Nossa Senhora das Graças e sua Presidente, Sra. Selma Maria Demoner e equipe, pela colaboração e ajuda.

Ao Conselho Nacional de Desenvolvimento Científico e Tecnológico (CNPq) e à Fundação de Amparo à Pesquisa do Estado de São Paulo (FAPESP, Processo № 07/03577-6), pelos auxílios financeiros.

Meus Sinceros Agradecimentos. 
"Eu chamo-vos amigos, porque vos deía contiecer tudo o que ouvi de meu Pá. Wão fostes vós que me escolhestes, mas fui eu que vos escollit' e vos designeipara írles e para que produzais fruto e o vosso frutopermaneça."

$200015,15-16$ 


\section{RESUMO}

Fabris AS. Análise bacteriológica de infecções pulpares em dentes decíduos. [tese (Doutorado em Microbiologia)] São Paulo: Instituto de Ciências Biomédicas da Universidade de São Paulo; 2011.

Foram analisados dentes decíduos com cárie dental profunda de 110 crianças, sendo coletadas 103 amostras de polpa necrosada e 7 de fístulas gengivais. Morfotipos bacterianos foram visualizados pelas colorações de Gram e BrennBrown, e os DNA foram obtidos e usados na detecção bacteriana por PCR. A predominância de cocos Gram-positivos (81,8\%) e cocobacilos Gram-negativos $(49,1 \%)$ foram observadas. Em 88 amostras de polpas, microrganismos com maior ocorrência foram: Enterococcus spp. (50\%), P. gingivalis (49\%), F. nucleatum (25\%) e $P$. nigrescens $(11,4 \%)$. Foram detectados em fístulas: $P$. gingivalis $(43 \%)$, Enterococcus spp. (28,6\%), F. nucleatum (14,3\%), P. nigrescens (14,3\%), e $D$. pneumosintes $(14,3 \%)$. Os resultados permitem concluir que a microbiota envolvida nas infecções pulpares em dentes decíduos é similar em termos qualitativos àquela observada em dentes permanentes. Entretanto, a predominância de Enterococcus spp. e $P$. gingivalis deve ser levada em consideração pelos clínicos em casos necessários de tratamento endodôntico em crianças com dentição decídua.

Palavras chave: Dente Decíduo. Infecções Pulpares. PCR. 


\begin{abstract}
Fabris AS. Bacteriological analysis of pulp infection in deciduous teeth. [Ph. D thesis (Microbiology)] São Paulo: Instituto de Ciências Biomédicas da Universidade de São Paulo; 2011.

In this study, deciduous teeth with deep caries from 110 children, with 103 pulp necrosis and 7 gingival fistula samples were evaluated. Bacterial morphotypes were visualized by Gram staining and Brown-Brenn. DNA were obtained and used in bacterial detection by using PCR. The predominance of Gram-positive cocci (81.8\%) and Gram-negative coccobacilli (49.1\%) were observed. In 88 pulp samples high frequencies of microorganisms were: Enterococcus spp. (50\%), P. gingivalis (49\%), F. nucleatum (25\%) and $P$. nigrescens (11.4\%). In fistulas were detected: $P$. gingivalis (43\%), Enterococcus spp. (28.6\%), F. nucleatum (14.3\%), P. nigrescens (14.3\%), and Dialister pneumosintes (14.3\%). Our results, suggest that the involved microbiota in pulp infections of deciduous teeth are qualitatively similar than those permanent teeth. However, a predominance of Enterococcus spp. and $P$. gingivalis was observed, and it must be considered in the endodontic treatment in children with primary dentition.
\end{abstract}

Keywords: Deciduous Teeth. Pulp Infection. PCR. 


\section{LISTA DE ILUSTRAÇÕES}

Figura 1. Coleta de amostra de polpa necrosada em segundo molar inferior esquerdo, em criança.

Figura 2. Coleta de amostra de fístula gengival na região de segundo molar inferior esquerdo, em criança. .46

Figura 3. Morfotipos bacterianos observados nas amostras de polpa necrosada e fístulas analisadas pelas colorações de Gram e Brenn-Brown (A). Associações de morfotipos bacterianos (B)

Figura 4. Detecção bacteriana por $P C R$ em 88 amostras clínicas de polpa necrosada de dentes decíduos. (A) bactérias detectadas individualmente, e (B) bactérias detectadas em associações 


\section{LISTA DE TABELAS}

Tabela 1 - Instituições, número de crianças examinados e coleta de amostras. .45

Tabela 2 - Iniciadores espécie-específico e condições de amplificação utilizadas na detecção bacteriana. .49

Tabela 3 - Características dos dentes com polpa necrosada e presença de fístulas.

Tabela 4 - Ocorrência bacteriana em 88 amostras clínicas de polpa necrosada e 7 fístulas gengivais nas diferentes faixas etárias e sexo. .52 


\section{SUMÁRIO}

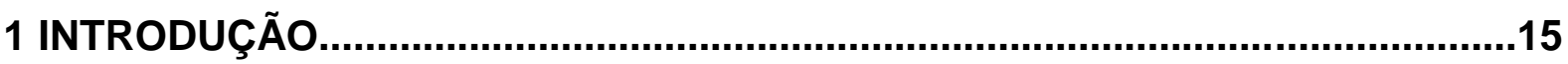

2 OBJETIVOS

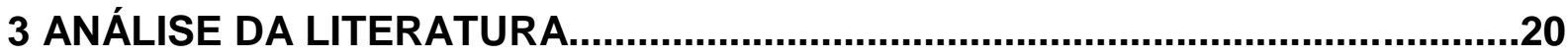

3.1 Características da dentição decídua humana e necrose pulpar.....................21

3.2 Microbiota presente na polpa necrótica de dentes permanentes.................24

3.3 Microbiota presente na polpa necrótica de dentes decíduos.........................37

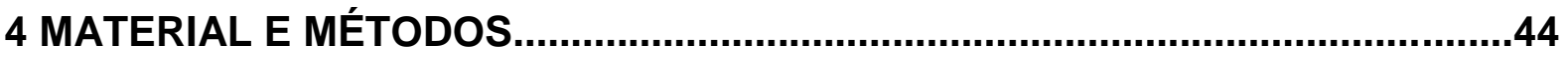

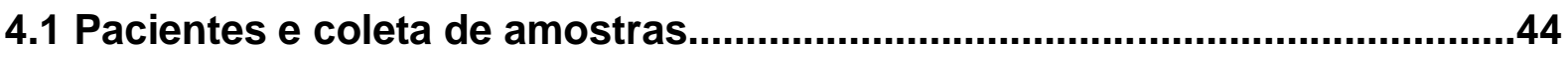

4.2 Análise de microbiota em amostras de polpas necrosadas e fístulas...........47

4.3 Detecção de microrganismos na polpa e fístula.............................................47

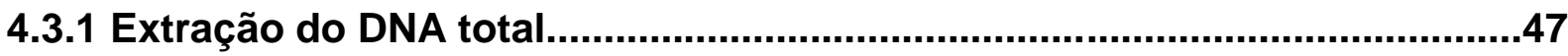

4.3.2 Amplificação do DNA por PCR....................................................................48

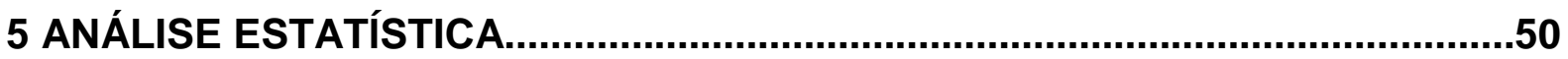

6 RESULTADOS

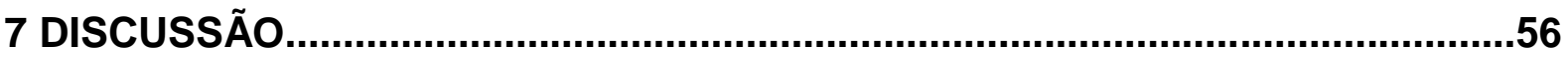

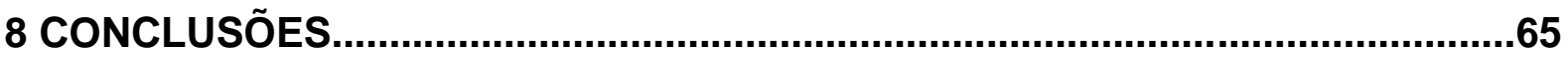

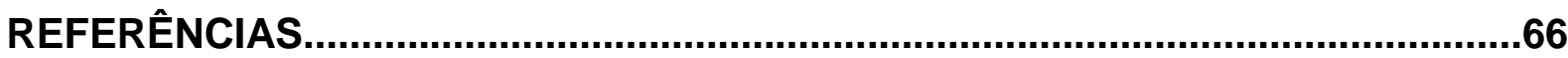

ANEXO - Termo de Consentimento e Livre Esclarecimento................................79 


\section{INTRODUÇÃO}

Em vários países, entre eles o Brasil, o exercício profissional na área de saúde tem estimulado o tratamento das doenças bucais, e não as diferentes formas de prevenção. Isso tem elevado a taxa de infecções nos estágios avançados, como nos processos endodônticos em dentes decíduos, onde há comprometimento da polpa (Reisine e Psoter, 2001; Cooper et al., 2010). Estudos realizados por Reeves e Stanley (1966), já relatavam que $75 \%$ dos dentes decíduos com cárie profunda podem desenvolver infecções na polpa dental.

Segundo dados do Ministério da Saúde (Brasil, 2004), a incidência de cárie na dentição decídua em crianças brasileiras é expressiva, particularmente, em crianças $\leq 3$ anos de idade; e em crianças entre 5 a 12 anos, apresentando pelo menos três dentes cariados. A presença de placa bacteriana e o tipo de dente são variáveis associadas com lesões ativas de cárie em superfícies oclusais de dentes decíduos (Braga et al., 2010).

Os dentes decíduos são importantes na infância, servindo como guia para a erupção da dentição permanente. Contribuem, também, para o desenvolvimento dos maxilares, junto ao processo da mastigação, preparando o alimento para a digestão e assimilação de nutrientes na etapa em que a criança está em crescimento. A perda prematura desses elementos dentais, além das sequelas estéticas, acarreta diminuição do espaço no arco dental, com alteração da guia de erupção do sucessor permanente, podendo trazer como consequências, problemas fonéticos e surgimento de hábitos bucais nocivos, tal como interposição da língua, entre outros (Cuoghi et al., 1998; Thilander, 2009).

No dente decíduo, a câmara pulpar é mais ampla em relação aos dentes permanentes, os cornos pulpares são mais proeminentes, podendo facilitar a exposição da polpa pela cárie dental ou lesão traumática, como fraturas dentais, levando à necrose do tecido (Linde, 1985; Morabito e Defabianis, 1992). A necrose pulpar implica na parada dos processos metabólicos da polpa dental, com a consequente perda de sua estrutura, bem como de suas defesas naturais. A exposição do tecido pulpar ao meio bucal e sua decomposição permitirão o livre acesso de microrganismos da microbiota oral a esse tecido oferecendo condições 
ideais para a proliferação microbiana no interior do canal radicular (Hobson, 1970; Sundqvist, 1994; Nagaoka et al., 1995; Bolan e Rocha, 2007; Cooper et al., 2010).

Segundo Kakehashi et al. (1965), a dinâmica de contaminação da polpa por microrganismos possui uma via direta (cárie dental, canalículos dentinários e fraturas dentais); outra por contiguidade (contaminação pela região vizinha); via linfática ou retrógrada (terapia periodontal e traumas físicos); e via hematogênica, através da corrente sanguínea, fenômeno denominado de anacorese.

Analisando a anatomia dos molares decíduos, entre a câmara coronária e a região óssea que envolve as raízes, a camada de dentina é pouco espessa, além de conter canais acessórios (Moss et al., 1965; Vermot-Gaud, 1967). Nessa área podem ocorrer comunicações entre a câmara pulpar e os tecidos periodontais, por onde também bactérias e suas toxinas, assim como os produtos da decomposição tecidual pulpar podem se difundir, resultando na reabsorção do tecido ósseo alveolar vizinho (Fanning, 1962; Winter, 1962; Morabito e Defabianis, 1992). Foi descrito também um provável acesso de bactérias presentes na microbiota oral pela junção gengiva-esmalte, quando o dente decíduo está em processo de reabsorção (Harokopakis-Hajishengallis, 2007). A invasão da polpa e áreas periapicais pode também promover o desenvolvimento de abscesso dento-alveolar e fístula, disseminando a infecção para outras áreas anatômicas próximas (MacDonald et al., 1957; Cohen et al., 1960; Shovelton, 1964; Akpata e Blechman, 1982; Brook, 2003).

A terapêutica da necrose pulpar em dentes decíduos sempre foi um tema complexo, devido: 1) à sua anatomia e irregularidades causadas pelas reabsorções fisiológicas que dificultam o acesso a todo o conduto radicular durante o tratamento (Vermot-Gaud, 1967; Morabito e Defabianis, 1992; Thomas et al., 1994; Rimondini e Baroni, 1995; Bolan e Rocha, 2007); 2) ao desconhecimento dos microrganismos, que podem estar envolvidos no processo infeccioso (Önçag et al., 2006; Silva et al., 2006; Rocha et al., 2008).

O tratamento endodôntico é uma rotina na prática clínica odontopediátrica e constitui uma das últimas manobras para que se possa preservar o dente que teve 0 tecido pulpar necrosado ou comprometido de forma irreversível (Marsh e Largent, 1967; Sjögren et al., 1997). Apesar de o tratamento ter sido descrito há algumas 
décadas, até hoje existem controvérsias para essa terapia, não existindo um protocolo definido ou padronizado (Thomas et al., 1994; Önçag et al., 2003; Dunston e Coll, 2008).

Os primeiros estudos publicados sobre a etiologia das infecções endodônticas em dentes decíduos mostraram a presença de bactérias aeróbias e facultativas, devido às limitações das técnicas de isolamento (Cohen et al., 1960; Marsh e Largent, 1967). Hobson (1970) observou em dentes decíduos cariados a presença de morfotipos bacterianos no interior dos túbulos dentinários e na região do assoalho da câmara pulpar. Com o surgimento de técnicas de cultivo para bactérias anaeróbias, surgiram novos estudos demonstrando que as infecções endodônticas são polimicrobianas e apresentando bactérias anaeróbias estritas (Brook et al., 1981; Toyoshima et al., 1988; Brook et al., 1991; Sato et al., 1993; Pazelli et al., 2003; Silva et al., 2006).

Em revisão da literatura, Brook et al. (2003) descreveram as espécies bacterianas mais predominantes em pulpites e em abscessos de origem endodôntica em crianças, correspondendo aos gêneros Streptococcus, Prevotella, Porphyromonas e Fusobacterium.

Em ecologia microbiana, tem sido demonstrado que algumas espécies bacterianas com baixa incidência nas diversas infecções podem ser espécies importantes dentro de consórcios mistos complexos, sendo resultado de alterações ambientais, no sentido de que elas poderiam se tornar dominantes, em resposta às mudanças nas condições que favorecem o seu crescimento (Sogin et al., 2006). Assim, de uma perspectiva ecológica, todas as espécies em uma comunidade mista devem ser detectadas e identificadas com êxito (Siqueira e Rôças, 2009).

Estudos moleculares recentes têm revelado que quase 700 espécies bacterianas distintas podem habitar a cavidade oral humana, embora nem todas elas colonizem o mesmo indivíduo ao mesmo tempo. Normalmente, cerca de 100 a 200 espécies fazem parte da microbiota oral, indicando que existe uma diversidade microbiana considerável nesse ecossistema (Paster et al., 2006).

Em adultos, algumas espécies bacterianas que são encontradas em infecções endodônticas (Kerekes e Olsen, 1990; Gharbia et al., 1994; Sundqvist, 1994; 
Conrads et al., 1997; Bogen e Slots, 1999; Siqueira et al., 2000; Fouad et al., 2002), também foram descritas em periodontites (Naito e Gibbons, 1988; Moore et al., 1985; Avila-Campos e Velásquez-Meléndez, 2002). Entretanto, em infecções de polpa e fístulas de crianças ainda não foi verificada essa relação. Trabalhos realizados em crianças da Turquia relatam elevada ocorrência de E. faecalis em infecções de polpa em dentes decíduos, mais isso ainda não foi pesquisado em outros países (Önçag et al., 2006; Cogulu et al., 2007; Cogulu et al., 2008a). 


\section{OBJETIVOS}

Este estudo teve como finalidade avaliar os microrganismos presentes em polpas necrosadas e fístulas de dentes decíduos, considerando a etiologia das doenças pulpares e periapicais como fator importante nos procedimentos endodônticos, assim como sua relação com a saúde geral dos pacientes, sendo avaliadas as seguintes características:

1. Observar a predominância dos respectivos morfotipos bacterianos em materiais clínicos de polpas necrosadas e fístulas;

2. Determinar a ocorrência de microrganismos em polpas necrosadas e fístulas de dentes decíduos, pelo método de PCR; e

3. Correlacionar a ocorrência bacteriana nas polpas necrosadas e fístulas de dentes decíduos, de acordo com a faixa etária e o sexo dos pacientes. 


\section{ANÁLISE DA LITERATURA}

A infecção endodôntica se caracteriza pela contaminação do sistema de canais radiculares dentários, sendo em sua grande maioria de origem bacteriana. Infecção endodôntica primária é causada por microrganismos que inicialmente invadem e colonizam o tecido pulpar necrótico, sendo caracterizada por uma população mista, composta em grande parte por bactérias anaeróbias, tendo em média 10 a 30 espécies por canal e variando de $10^{3}$ a $10^{8}$ células (Möller, 1966; Wittgow e Sabiston, 1975; Keudell et al. 1976; Siqueira e Rôças, 2004; Siqueira e Rôças, 2009).

A infecção endodôntica secundária é causada por microrganismos que não estão presentes na infecção primária, mas que foram introduzidos no canal em algum momento, particularmente, após a intervenção profissional. Esses microrganismos presentes nas infecções primárias ou secundárias resistem à privação de nutrientes nos canais tratados e aos antimicrobianos utilizados no tratamento. Microrganismos persistentes principalmente nas infecções secundárias são as principais causas de problemas clínicos, incluindo a falha do tratamento endodôntico, que é caracterizada pelo aparecimento de periodontite apical em adultos (Engstrom e Frostell, 1964; Möller, 1966; Nair et al., 1990; Tronstad et al., 1990; Hashioka et al., 1992; Wayman et al., 1992; Sundqvist et al., 1998; Peciuliene et al., 2000; Stuart et al., 2006; Siqueira e Rôças, 2009).

Estudos empregando métodos de cultura e PCR têm demonstrado que infecções endodônticas primárias apresentam microrganismos estritamente anaeróbios. Falhas no tratamento endodôntico, são frequentemente associadas a microrganismos Gram-positivos aeróbios e facultativos. A presença de E. faecalis na falha do tratamento endodôntico é amplamente descrita na literatura e raramente detectado em casos primários não tratados em adultos (Sundqvist et al., 1998). Apesar de infecções secundárias ainda não terem sido relatadas em canais radiculares de dentes decíduos (Silva et al., 2006; Ruviére et al., 2007; Cogulu et al., 2008a; Yang et al., 2010), a presença de biofilmes tem sido visualizada em regiões de reabsorções externas da raiz, protegendo os microrganismos da ação dos antimicrobianos usados no tratamento (Godoy, 1999; Bolan e Rocha, 2007; Rocha et al., 2008). 
A terapêutica endodôntica tem como meta a máxima eliminação da infecção instalada no sistema de canais. O término da infecção do canal radicular propicia um ambiente favorável ao reparo das lesões periapicais, enquanto a persistência de microrganismos exerce um papel importante nos insucessos do tratamento endodôntico (Sjögren et al., 1997).

A morfologia do sistema de canais radiculares determina áreas inacessíveis ao preparo biomecânico, como canais laterais, acessórios, secundários, deltas apicais e túbulos dentinários, contribuindo para a permanência de microrganismos nessas regiões (Nair et al., 1990; Morabito e Defabianis, 1992; Oguntebi, 1994; Siqueira et al., 1996). Embora fatores não microbianos endógenos ou exógenos possam estar envolvidos, microrganismos e seus produtos são os principais responsáveis pelo fracasso do tratamento endodôntico (Lin et al., 1991). Na maioria das vezes, uma infecção persistente do canal radicular é resultante de um preparo químico-mecânico ou de uma medicação intracanal inadequados. Entretanto, em algumas situações, a realização adequada das medidas de controle da infecção pulpar, não elimina todos os microrganismos, uma infecção persistente pode se desenvolver, e esses organismos podem apresentar resistência aos agentes antimicrobianos empregados (Thomas et al., 1994; Card et al., 2002; Önçag et al., 2003; Önçag et al., 2006; Gomes et al., 2006; Cogulu et al., 2008b).

\subsection{Características da dentição decídua humana e necrose pulpar}

A formação da dentição decídua tem início durante as seis primeiras semanas de vida intra-uterina. A erupção dos primeiros dentes decíduos se dá por volta dos seis meses de idade. Normalmente, o término ocorre de 24 a 30 meses após o nascimento da criança, quando os segundos molares decíduos entram em oclusão. Poucas alterações costumam ocorrer na dentição decídua, no período que vai de 2,5 aos 5 anos de idade. Isso se aplica às posições dentárias individuais e também à relação transversa e sagital das arcadas. Nesse período os dentes permanentes estão finalizando a formação intra-óssea (Thilander, 2009).

Barnett e Mehta (1970) descreveram as características de desenvolvimento da oclusão dentária. A dentição decídua é composta de vinte dentes em cada arcada, com erupção ocorrendo sequencialmente, completando-se aos três anos de 
idade. A erupção dos primeiros molares permanentes e início da dentição mista ocorrem aos 6 anos de idade; e a troca dos incisivos entre 6 a 9 anos; dos caninos e molares decíduos entre 9 a 12 anos, e erupção dos segundos molares permanentes entre 12 e 13 anos. Os terceiros molares nessa época ainda estão em processo de formação intra-ósseo.

A época e o modo pelos quais os dentes erupcionam podem influenciar o curso clínico de afecções bucais, como a ocorrência da cárie dentária e o futuro desenvolvimento da oclusão. A precocidade ou atraso da erupção de todos ou de alguns dentes, bem como a sequência atípica, relacionam-se aos padrões de distribuição da cárie e algumas classes de más-oclusões, constituindo motivo de atenção por parte do clínico (Gorski e Marks, 1992).

A reabsorção fisiológica em dentes decíduos com infecção endodôntica e lesão periapical apresentam grandes áreas de reabsorção e discretas áreas de reparação, quando comparadas à reabsorção em dentes decíduos sadios. Entretanto, dentes tratados endodonticamente e livres de infecção são reabsorvidos aparentemente em um padrão de normalidade. Traumas oclusais e lesões cariosas profundas normalmente aceleram a reabsorção, adiantando a exfoliação. $O$ tratamento dos canais radiculares, portanto, é importante não somente para a preservação do mesmo até a época de sua exfoliação fisiológica, mas também para proteger o germe dentário do dente permanente em desenvolvimento, desde que não haja contraindicação para sua manutenção. Paralelamente ao processo de reabsorção, ocorre a odontogênese e a erupção do sucessor permanente (Fanning, 1962; Baroni e Rimondini, 1992; Rimondini e Baroni, 1995; HarokopakisHajishengallis, 2007).

Winter (1962) estudou alterações radiográficas associadas com a formação de abscessos em molares decíduos de 45 crianças com 3 a 10 anos. A alteração mais comum foi uma rarefação inter-radicular com intensidade máxima na bifurcação das raízes, quando o sucessor permanente subjacente estava em sua posição normal. Também, verificou a formação de canais acessórios e reabsorções macroscópicas na dentina entre as raízes de 100 molares decíduos extraídos. Foi constatada a formação de canais acessórios em $29 \%$ dos dentes, afirmando que nesses casos a formação de abscessos pode ser explicada pela presença desses 
canais ou áreas de reabsorção radicular, formando comunicações entre canal radicular e tecido inter-radicular.

Microscopicamente, a polpa apresenta uma fileira de odontoblastos em contato com a dentina, que contornam a periferia do espaço pulpar, estendendo seus processos citoplasmáticos para dentro de túbulos dentinários. A zona livre de células se localiza logo abaixo da camada odontoblástica e contém um amplo plexo de nervos não mielinizados e capilares sanguíneos circundados por tecido conjuntivo frouxo, formado por células e matriz extracelular. Os fibroblastos são as principais células encontradas em toda a extensão da polpa. Outros tipos celulares também são encontrados como: células mesenquimais indiferenciadas, endoteliais, neurais, e do sistema imune. O colágeno é o elemento fibroso mais abundante, presente em toda a polpa. As proteínas colágenas produzidas pelos fibroblastos pulpares são os maiores constituintes da matriz extracelular, e também constituem o maior componente orgânico da matriz da dentina (80 a 90\%), sendo encontrado o tipo I e, em menor número, fibrilas colágenas dos tipos III e IV, correspondentes às fibrilas reticulares (Linde, 1985; Agematsu et al., 1997).

A dentina é depositada pela polpa durante toda a vida, sendo capaz de reagir aos estímulos fisiológicos e patológicos, provocando alterações reparatórias na superfície pulpar subjacente a uma área onde os prolongamentos dos odontoblastos tenham sido lesionados. Quando ocorre o avanço do processo carioso do esmalte à dentina, há a formação de dentina esclerótica por justaposição dos minerais para dentro e entre os túbulos, e secreção de dentina de reparação ou terciária por outras células mesenquimais da polpa que se diferenciam em novos odontoblastos. A qualidade e quantidade de dentina terciária dependem da profundidade e do grau de progressão da lesão cariosa, e quanto mais rápida for essa progressão, mais pobre e irregular será a dentina de reparação. Quando o processo carioso avança, ocorre dilatação dos vasos sanguíneos pulpares observando-se células inflamatórias, subjacentes às áreas dos túbulos dentinários envolvidos. Caso a lesão cariosa permaneça sem tratamento, ocorrerá a exposição e infecção, e a polpa reagirá com uma inflamação aguda. À medida que a lesão progride, a polpa poderá sofrer necrose parcial, seguida de necrose total (Reeves e Stanley, 1966; Shovelton, 1968; Cooper et al., 2010). 
Moss et al. (1965), estudaram a possibilidade da difusão de material necrótico da polpa através do assoalho da câmara pulpar até a região interradicular via canais acessórios ou através da dentina e cemento na qual a permeabilidade do assoalho pudesse estar alterada na presença de infecção. Nesse estudo, os autores compararam a porosidade do assoalho da câmara pulpar de molares decíduos infectados e controles através da perfusão de corantes e exames histológicos de secções seriadas da região. Os resultados obtidos demonstraram uma maior permeabilidade do assoalho da câmara pulpar nos molares decíduos infectados. Assim, a maior permeabilidade e alterações histopatológicas na dentina e cemento contribuiriam para o fluxo constante de material necrótico, a partir do assoalho da câmara pulpar, até a região inter-radicular.

Vermot-Gaud (1967) analisou a importância da presença de canais acessórios na propagação da infecção pulpar em molares decíduos através de exames radiográficos e histológicos de secções seriadas. Os resultados demonstraram a complexidade do sistema de canais radiculares e a presença de grande número de canais secundários, principalmente ao nível do delta apical. Esses canais levariam a infecção pulpar em direção ao ligamento periodontal e sua existência condicionaria a localização das alterações entre as raízes nos molares decíduos.

Segundo Hobson (1970), a presença de microrganismos penetrando profundamente nos túbulos dentinários no assoalho da câmara pulpar sugere que toxinas possam ter acesso à região inter-radicular por essa via, determinando a área típica radiolúcida em radiografias verificada nos molares decíduos. Além disso, a reabsorção radicular e a presença de processos inflamatórios podem ainda determinar danos na camada protetora de cemento, expondo túbulos dentinários e facilitando ainda mais a passagem de bactérias e produtos tóxicos à superfície radicular.

\subsection{Microbiota presente na polpa necrótica de dentes permanentes}

A presença de morfotipos bacterianos foi descrita há mais de um século por Miller (1894), estudando 250 dentes com polpas inflamadas e necróticas, decorrentes de cárie dental. Utilizando culturas e colorações bacteriológicas, 
concluiu que a gravidade da inflamação geralmente não parece ser proporcional ao número de bactérias presentes, e sim à ação dessas bactérias e de seus produtos nos tecidos.

Boyle (1934), utilizando métodos de coloração, evidenciou bacilos Grampositivos no interior de células fagocitárias na porção central de um granuloma periapical.

Estudando 70 dentes com coroas intactas, sem vitalidade pulpar relacionada a trauma, Brown e Rudolph (1957) empregaram técnicas de cultivo, microscopia de contraste de fase e campo escuro, encontrando bactérias em $90 \%$ das amostras. Os autores enfatizaram a importância do uso da microscopia no estudo da microbiota de canais radiculares devido à facilidade de detecção de vibriões, espiroquetas e fusiformes, que não apresentaram crescimento em cultura. No mesmo ano, MacDonald et al., isolaram 71 cepas bacterianas, em amostras de canais, obtidas de 46 dentes humanos subsequente a trauma, com coroas intactas e necrose pulpar. Também, determinaram que a maioria das bactérias atinge a polpa dos dentes que sofrem traumas dentários sem fraturas, via vasos linfáticos e sanguíneos do periodonto, podendo essa ser a causa da necrose pulpar.

Engstrom e Frostell (1964) avaliaram a prevalência do gênero Enterococcus spp. em infecções endodônticas, sendo encontrado em $21 \%$ dos canais com tratamento endodôntico prévio e em apenas $12 \%$ de canais com necrose pulpar.

Um dos primeiros estudos divulgados na literatura que buscava avaliar a disseminação da infecção no sistema de canais radiculares foi o desenvolvido por Shovelton (1964). Foram selecionados 97 dentes, clinicamente sem vitalidade pulpar, decorrentes de cárie ou trauma. Após serem extraídos, foram analisados por microscopia óptica, sendo que, 61 dentes continham bactérias no interior da dentina radicular, havendo maior concentração na região cervical quando comparada com ao terço médio e apical da raiz.

Usando a microscopia óptica, Kakehashi et al. (1965) observaram a importância de microrganismos na etiologia das infecções pulpares. 15 animais convencionais e 21 livres de germes tiveram os molares expostos ao meio bucal. Após 42 dias, os ratos foram sacrificados e a região maxilar exposta foi removida 
para processamento e coloração. Nos animais convencionais, as amostras obtidas no oitavo dia apresentavam tecido pulpar remanescente somente na metade apical das raízes, enquanto a polpa coronária mostrava-se necrótica, purulenta e frequentemente com biofilme bacteriano. Após esse período, demonstraram necrose pulpar com tecido inflamado crônico e formação de abscessos na região periapical. Os animais livres de germes apresentaram os dentes com mínima inflamação pulpar, porém, com vitalidade preservada. Concluíram que a presença de microrganismos torna-se fator determinante em polpas necróticas expostas ao meio bucal, sendo o processo de cárie dental uma via direta de contaminação da polpa por microrganismos da microbiota oral.

Estudos procurando caracterizar a microbiota associada aos dentes com insucesso endodôntico mostraram diferenças marcantes em relação aos casos de infecção primária. Möller (1966) verificou um menor número de microrganismos presentes no canal radicular de dentes com fracasso da terapia endodôntica quando comparados aos dentes com polpas necróticas. Foi verificado um equilíbrio entre as bactérias facultativas e anaeróbias estritas, com predomínio das Gram-positivas, correspondendo a $80 \%$ dos isolados, e E. faecalis apresentou uma incidência de $29 \%$.

Shovelton (1968), em revisão da literatura sobre as lesões de cárie dentinárias profundas, relatou que mesmo após a remoção total do tecido cariado, túbulos dentinários infectados ainda persistem. Porém, o número de microrganismos remanescentes nos túbulos é significantemente menor que na região superficial da lesão, e microrganismos podem permanecer viáveis, com capacidade para invadir a polpa.

Uma vez que a cárie é a principal causa da perda de vitalidade dos dentes, Kantz e Henryum (1973) determinaram pelo método de cultivo a prevalência de $S$. mutans, importante microrganismo cariogênico, em 19 amostras de canais radiculares humanos infectados. 12 (63\%) foram positivas, sendo sugerido que a prevalência microbiana não foi muito alta em canais radiculares infectados.

Wittgow e Sabiston (1975) avaliaram o perfil bacteriológico de dentes portadores de polpa mortificada por traumatismo. Bastonetes Gram-negativos foram 
evidenciados em $67 \%$ e os autores afirmaram que as espécies Eubacterium alactolyticum, Lactobacillus spp., Arachnia propionica, Propionibacterium acnes, Bacteroides ruminicola subspecie brevis, Bacteroides oralis, Bacteroides spp., Parvimonas micra, Peptostreptococccus intermedius, Peptostreptococccus anaerobius, Veillonella parvula; e organismos facultativos: Staphylococcus aureus, Actinomyces spp. e Estreptococcus spp. fazem parte da microbiota oral.

Keudell et al. (1976), utilizando cultivo bacteriológico, isolaram microrganismos presentes em 43 amostras de câmaras pulpares infectadas. Bactérias foram encontradas em $79 \%$ das amostras provenientes de polpas necróticas, sendo 64\% anaeróbias, com destaque para as espécies: Bacteroides spp., Propionibacterium acnes e Eubacterium alactolyticum. Entretanto, os autores afirmaram que o gênero Streptococcus foi o mais frequentemente isolado. Uma maior tendência em abrigar microrganismos anaeróbios foi verificada em polpas necrosadas de dentes traumatizados quando comparados à necrose por evolução de processo carioso.

Fabricius et al. (1982), avaliaram a capacidade de 11 espécies bacterianas em combinações para induzir reações periapicais. As bactérias orais foram originalmente isoladas de processo periapical experimental em macacos. No final do período experimental, verificou-se que nas infecções mistas Prevotella oralis predominou na maioria dos canais radiculares somente em associações com outras bactérias. Enterococcus spp. no entanto, sobreviveu como cultura pura em todos os canais. Os autores verificaram que as bactérias, ocorrendo em infecções mistas, apresentaram a maior capacidade de induzir periodontite apical.

A microscopia óptica foi o método utilizado por Akpata e Blechman (1982) para estudar em 14 dentes unirradiculados a colonização bacteriana nas paredes da dentina pulpar e túbulos dentinários. Os canais radiculares foram inoculados com Prevotella melaninogenica, Peptococcus assacharolyticus, E. faecalis e S. sanguis. Após o período de incubação de 1 a 3 semanas, os espécimes foram preparados para análise microscópica pela técnica de coloração de Brenn e Brown. No final da primeira semana, poucos túbulos dentinários do terço cervical da raiz haviam sido invadidos. A presença de $P$. melaninogenica e $P$. assacharolyticus foi relativamente pequena, provavelmente devido ao crescimento exigente. 
Nair (1987) examinou 31 dentes portadores de lesões periapicais e sem tratamento endodôntico. Usando microscopia óptica, mostrou a presença bacteriana em todos os canais, constituindo uma microbiota mista, representada por cocos, bacilos, formas filamentosas e espiroquetas. Em microscopia eletrônica de varredura, biofilme bacteriano pode ser identificado aderido às paredes dentinárias. Porém, uma pequena porção das lesões periapicais revelou bactérias dentro do corpo das lesões. Posteriormente, usando microscopia óptica e eletrônica de transmissão, Nair et al. (1990) avaliaram nove dentes tratados endodonticamente e portadores de lesões periapicais persistentes após 4 a 10 anos. Foram observadas áreas de reabsorções internas ocupadas por denso biofilme bacteriano de forma filamentosa. Os autores sugerem que as lesões persistentes ao tratamento endodôntico estão relacionadas a fatores que permitem a viabilidade de microrganismos residuais no sistema de canal radicular após tratamento endodôntico.

Sundqvist et al. (1989), analisaram 72 dentes unirradiculados portadores de polpas necróticas e periodontites apicais. Os resultados evidenciaram elevada porcentagem de bactérias anaeróbias (90\%) e bacilos produtores de pigmento negros (30\%). 16 dos dentes apresentaram abscesso apical agudo purulento, os outros seis dentes foram assintomáticos. As espécies mais frequentes foram: $F$. nucleatum, P. intermedia, P. endodontalis, Parvimonas micra, $P$. anaerobius e Eubacterium alactolyticum.

Em revisão da literatura, Kerekes e Olsen (1990) analisaram a microbiota de canais radiculares e bolsas periodontais profundas, com o objetivo de verificar suas correlações. Concluíram que a infecção crônica no canal radicular ou ligamento periodontal pode representar um suprimento persistente de bactérias para a circulação sanguínea, podendo atingir partes não infectadas do dente, como também órgãos do corpo humano.

Tronstad et al. (1990) estudaram por microscopia a superfície radicular dos terços apicais de dez dentes portadores de lesões periapicais persistentes que, após tratamento endodôntico convencional, foram removidos cirurgicamente. Observaram microrganismos em todas as amostras, principalmente em áreas irregulares da superfície radicular entre feixes de fibras colágenas e células. Além de cocos e 
bacilos, formas filamentosas ou fibrilares foram também identificadas. Os autores sugerem que a procedência desses microrganismos seja da cavidade oral, sem descartar a via hematogênica.

Lin et al. (1991), analisaram 150 dentes com insucessos endodônticos, com período de observação variando de 6 meses a 14 anos. Observaram reabsorção radicular apical associada à inflamação severa. Edema, dor e fístula, foram frequentemente associados com presença de bactérias no canal radicular e, ocasionalmente, nos tecidos periapicais. Os autores correlacionaram infecção bacteriana com a maioria dos fracassos endodônticos.

Correlacionando a composição da microbiota de canais infectados de pacientes portadores de periodontites apical com sintomas clínicos, Hashioka et al. (1992) realizaram estudo bacteriológico dos canais radiculares de 28 dentes. Os resultados evidenciaram uma significante relação entre Eubacterium spp. e sintomas clínicos agudos ou crônicos, enquanto, Peptococcus spp., Peptostreptococcus spp. e $P$. gingivalis foram relacionados aos sintomas clínicos subagudos.

A microbiota dos canais radiculares foi verificada em 65 dentes unirradiculados com polpas necróticas, por Sundqvist (1992). 353 cepas bacterianas foram isoladas, sendo $F$. nucleatum o mais frequente $(48 \%)$, seguido por $P$. intermedia, P. micros, P. anaerobius, E. alactolybicum e Campylobacter rectus. Observou-se que diferentes espécies bacterianas apresentam um sinergismo positivo, formando uma cadeia alimentar pela qual o metabolismo de algumas espécies forneceria nutrientes essenciais para 0 crescimento de outras. Posteriormente, em revisão da literatura, Sundqvist (1994) concluiu que bactérias presentes em canais infectados incluem um grupo restrito de espécies comparadas com a microbiota da cavidade bucal. Durante o curso da infecção pulpar, desenvolvem-se inter-relações entre espécies microbianas, proporcionando mudanças consideráveis na microbiota, constituindo-se de associações resistentes e com interdependência mútua. A patogenicidade da microbiota do canal radicular está na dependência desse sinergismo bacteriano.

Com o propósito de verificar microrganismos em lesões periapicais persistentes após tratamento endodôntico, Wayman et al. (1992) estudaram 58 
casos de lesões periapicais de origem endodôntica por meio de microscopia óptica e culturas. As bactérias isoladas com mais frequência foram: Parvimonas micra, $F$. nucleatum e $P$. intermedia. Concluindo que bactérias anaeróbias são importantes para a persistência das lesões crônicas.

Após revisão, Oguntebi (1994) sugeriu que o microambiente dos túbulos dentinários parece favorecer o crescimento de algumas espécies bacterianas. Estas constituem um importante reservatório bacteriano dos canais radiculares infectados, sendo capazes de reinfectá-lo durante ou após o tratamento endodôntico.

Nagaoka et al. (1995) estudaram a diferença na resistência à invasão bacteriana nos túbulos dentinários entre dentes vitais e sem vitalidade. Foram selecionados 19 pares de terceiros molares superiores de adultos jovens do sexo masculino. Restaurações e pulpectomias foram realizadas de forma unilateral, e uma cavidade envolvendo a dentina foi feita na superfície palatina dos dentes de ambos os grupos. Decorridos 150 dias de exposição, a invasão bacteriana para o interior dos túbulos dentinários dos dentes desvitalizados foi significantemente maior. Os resultados sugerem que os prolongamentos odontoblásticos, matriz extracelular e o fluido dentinário podem dificultar a penetração bacteriana nos túbulos dentinários dos dentes com vitalidade.

Siqueira et al. (1996) estudaram a penetração de bactérias em túbulos dentinários, utilizando cilindros de dentina obtidos a partir de incisivos bovinos recém-extraídos e $P$. endodontalis, $P$. gingivalis, $F$. nucleatum, Actinomyces israelii, $P$. acnes e $E$. faecalis foram incubados em anaerobiose. Assim, foi observado através de microscopia eletrônica de varredura, que todas as espécies bacterianas empregadas no experimento foram capazes de penetrar nos túbulos dentinários em diferentes profundidades. Os autores relataram que bactérias localizadas nos túbulos a uma pequena distância da superfície pulpar poderiam ser removidas pela preparação mecânica dos canais radiculares ou serem destruídas pela ação química das soluções irrigadoras; contudo, aquelas localizadas mais profundamente poderiam permanecer e se multiplicar, causando danos aos tecidos periapicais próximos. 
Sundqvist et al. (1998) avaliaram a microbiota presente em dentes que apresentaram insucesso no tratamento endodôntico. Os casos selecionados para o estudo apresentavam lesão óssea periapical radiograficamente visível, caracterizando a necessidade de retratamento. Os resultados detectaram na maioria dos casos monoinfecção constituída principalmente por Gram-positivos (87\%), anaeróbias facultativas (58\%) e estritas (42\%). O microrganismo mais comumente recuperado foi $E$. faecalis $(38 \%)$.

Bogen e Slots (1999) determinaram a frequência de bacilos produtores de pigmento negro em amostras de saliva, sulco gengival, e lesões periapicais refratárias utilizando PCR. $P$. gingivalis foi detectada em uma amostra de lesão periapical e $P$. endodontalis em oito subgengivais. Entretanto, $P$. nigrescens, $P$. endodontalis, $P$. intermedia não foram encontradas, concluindo-se que esses microrganismos são raros em lesões periapicais.

Peciuliene et al. (2000), utilizando cultivo bacteriológico, investigando 25 dentes tratados endodonticamente, assintomáticos e com periodontites apicais visíveis radiograficamente, encontraram E. faecalis em $70 \%$ das amostras. Peciuliene et al. (2001), ampliando a amostra do estudo anterior, encontraram microrganismos em 33 de 40 dentes avaliados. Candida albicans estava presente em $6(18 \%)$ e bacilos entéricos Gram-negativos em 3 casos. E. faecalis estava presente em 21 canais (64\%), sendo o único componente da microbiota em 11 casos.

Siqueira et al. (2000) analisaram 21 canais radiculares de pacientes adultos com cárie, necrose pulpar e evidência de perda óssea perirradicular. Utilizando PCR detectaram $T$. denticola em 11, sendo 8 casos assintomáticos e três sintomáticos à percussão. As espécies bacterianas encontradas em polpas infectadas são geralmente as mesmas que as isoladas de bolsas periodontais.

Hancock et al. (2001) avaliaram a composição da microbiota presente em 54 dentes com insucesso do tratamento endodôntico. A microbiota era composta predominantemente de microrganismos Gram-positivos (80,4\%). Os gêneros mais isolados foram: Actinomyces, Enterococcus, Peptostreptococcus e Streptococcus. E. 
faecalis foi o mais frequentemente isolado, estando presente em $30 \%$ das amostras com crescimento bacteriano.

Siqueira et al. (2002) investigaram o padrão da infecção microbiana em canais radiculares infectados associados a lesões periapicais crônicas. Todos os canais examinados estavam infectados, a microbiota continha cocos e bastonetes formando densos agregados contínuos à parede do canal radicular, e em alguns casos penetrando nos túbulos dentinários. Os pesquisadores relataram a presença de biofilme bacteriano coagregados e organizados em comunidades, permitindo o estabelecimento e a sobrevivência de determinadas espécies bacterianas que requerem condições específicas e complexas para seu crescimento.

Fouad et al. (2002) determinaram a presença por PCR em amostras de dentes necrosados com periodontite apical de F. nucleatum, P. micra, Streptococcus spp. e $P$. nigrescens. Uma associação positiva foi descrita entre edema e a presença de Streptococcus spp. e P. gingivalis. Contudo, os autores não conseguiram demonstrar a relação entre a presença dessas espécies e a manifestação de sintomas.

Pinheiro et al. (2003), através da avaliação microbiológica de canais radiculares que necessitavam retratamento endodôntico, verificaram que E. faecalis foi a espécie bacteriana mais comumente recuperada, ocorrendo em $53 \%$ dos canais radiculares, sendo identificado como espécie única em 18.

Rôças et al. (2003) analisaram por nested PCR amostras de 32 canais radiculares com periodontite apical aguda. T. denticola foi detectado em $80 \%$, enquanto, T. socranskii e T. vincentii em 40\% e 10\% das amostras, respectivamente. Com base nesses dados, os autores relataram que esses microrganismos devem ser incluídos no conjunto restrito de possíveis patógenos endodônticos.

E. faecalis é um microrganismo que pode sobreviver em desafios extremos. Sua patogenicidade varia de doenças fatais em indivíduos comprometidos, a até doenças menos graves, como infecções de canais radiculares. Kayaoglu e Ørstavik (2004) revisaram os fatores de virulência da bactéria relacionados à infecção endodôntica e resposta inflamatória perirradicular, e sugeriram que fatores de 
agregação, adesinas de superfície, ácido lipoteicóico, produção de superóxido extracelular, gelatinase, hialuronidase, e citolisina podem estar envolvidos.

Rôças et al. (2004), utilizando PCR, compararam a prevalência de E. faecalis em canais não tratados e em canais com tratamento endodôntico prévio associados a lesões periapicais crônicas. E. faecalis foi isolado em 20 (67\%) de 30 dentes com insucesso do tratamento endodôntico, e em 9 (18\%) de 50 casos de infecções primárias. Nesse mesmo ano, Siqueira e Rôças investigaram a ocorrência de 19 espécies microbianas em 22 amostras de canais radiculares de dentes com insucesso do tratamento endodôntico. Todas as amostras foram positivas para $E$. faecalis, Pseudoramibacter alactolyticus e Propionibacterium propionicum, sendo a primeira a mais prevalente $(77 \%)$.

Sedgley et al. (2005) realizaram estudos para determinar a capacidade de sobrevivência do $E$. faecalis após a obturação definitiva do canal sem aporte nutricional, sendo recuperado após 6 meses e 1 ano de incubação. Esses resultados demonstram a capacidade que tem esse microrganismo de sobreviver a grandes desafios ambientais e de permanecer por um longo período no interior de canais radiculares obturados, podendo comprometer o tratamento. Em 2006, Sedgley et al., utilizando PCR, pesquisaram a ocorrência de E. faecalis em 136 sítios de 41 pacientes adultos. A bactéria foi encontrada em 12 (29\%) amostras de enxágue bucal, 22 (55\%) de dorso de língua, 7 (22\%) de sulco gengival, e 2 (9\%) de conduto radicular. Os dados indicam que a ocorrência na cavidade oral pode ser maior do que anteriormente sugerida na literatura, podendo a bactéria estar presente em sítios da cavidade oral, e posteriormente, contaminar canais radiculares.

Gomes et al. (2006) investigaram a prevalência de E. faecalis em 50 amostras de canais com necrose pulpar e 50 com insucesso do tratamento endodôntico, utilizando cultura e PCR como métodos de avaliação. Nos casos de retratamento, E. faecalis foi encontrado em 21 casos (42\%) pela cultura e em 38 casos (76\%) por PCR. Em 50 casos de infecção primária, a espécie foi observada em 2 (4\%) e 41 $(82 \%)$ canais, respectivamente, usando-se cultivo e PCR. Segundo os autores, o crescimento dessa espécie bacteriana pode ser favorecido por mudanças ecológicas no canal radicular após o preparo químico-mecânico ou obturação deficiente do canal radicular. 
$\mathrm{Na}$ identificação de bactérias pelos métodos tradicionais de cultivo e mais recentemente por estudos moleculares, mais de 700 espécies foram identificadas na cavidade bucal humana. Dessas, mais da metade ainda não pode ser cultivada, sendo 400 identificadas a partir de bolsas periodontais, e 300 de outros locais, tais como dorso da língua, mucosa bucal, lesões de cárie, e infecções endodônticas. Algumas bactérias, como Streptococcus spp. e. Veillonella spp., estão sempre presentes na maioria dos indivíduos e colonizam vários nichos orais. Em revisão, Paster et al. (2006) afirmaram que a amplitude da diversidade de bactérias na cavidade oral é verdadeiramente notável, com locais apresentando um perfil microbiano distinto. Várias espécies de bactérias, incluindo aquelas que não podem ser cultivadas, têm sido associadas à saúde ou à doença oral, sendo algumas dessas espécies associadas a doenças sistêmicas, tais como endocardite, prematuros de baixo peso, e doença cardíaca coronária.

Tomazinho e Avila-Campos (2007) avaliaram a prevalência de bactérias anaeróbias produtoras de pigmento negro em 100 amostras de infecções endodônticas crônicas utilizando cultura e PCR. $P$. intermedia foi detectada em $31,7 \%$ das amostras, $P$. nigrescens em 43,3\%, $P$. gingivalis em 43,3\%, e $P$. endodontalis $23,3 \%$. Os autores concluíram que, a presença desses anaeróbios de forma isolada ou em associações nas infecções endodônticas crônicas são fatores importantes no desenvolvimento e progressão da doença.

Jacinto et al. (2008) estudaram 110 amostras de dentes com infecções periapicais por métodos de cultura e usaram E-Teste para determinar a susceptibilidade antimicrobiana. Foram isoladas 580 cepas, sendo 81,4\% anaeróbios estritos. F. nucleatum foi encontrado em 38 canais radiculares, estando associado com $P$. gingivalis, Prevotella spp. e Eubacterium spp. F. necrophorum foi encontrado em 20 canais radiculares, estando associados a Peptostreptococcus prevotii. Todos foram $100 \%$ sensíveis à amoxicilina e cefaclor. Relataram que Fusobacterium spp. são frequentemente isoladas de canais radiculares com infecções primárias de dentes com patologias periapicais, sendo a amoxicilina útil contra F. nucleatum e F. necrophorum em infecções endodônticas.

Kishen et al. (2008), utilizando microscopia de fluorescência, observaram que a adesão de $E$. faecalis sobre dentina humana aumentava significativamente após a 
irrigação da dentina com EDTA a 17\%, enquanto que o hipoclorito de sódio (5,2\%) a reduziu. A força de aderência aumentou com o uso de clorexidina a $2 \%$, mas mostrou uma redução no número de bactérias aderidas. O regime de irrigação com EDTA, hipoclorito de sódio, e clorexidina resultou no menor número de $E$. faecalis aderidos. $\mathrm{O}$ estudo destaca que as substâncias químicas alteram as propriedades físico-químicas da dentina, podendo influenciar a natureza de adesão, força de aderência e formação de biofilme na dentina.

Pirani et al. (2008) avaliaram dentes com lesão periapical primária e secundário, sendo $E$. faecalis detectado em $7,6 \%$ de canais com infecção primária, e $29,1 \%$ com infecção secundária, e a presença desse microrganismo foi associada à ocorrência de infecção endodôntica secundária.

Saito et al. (2008) estudaram a interação molecular entre $F$. nucleatum, $P$. gingivalis e outros microrganismos isolados de lesões periapicais utilizando placas de poliestireno revestidas de colágeno em condições anaeróbias. F. nucleatum apresentou forte aderência ao poliestireno com colágeno tipo I. A formação de biofilmes por $F$. nucleatum foi significativamente aumentada por $P$. gingivalis e ligeiramente reduzida pela inativação do seu gene luxS. Os resultados sugeriram que $P$. gingivalis aumenta a formação do biofilme quando associada ao $F$. nucleatum.

Siqueira e Rôças (2008) investigaram a prevalência de $P$. gingivalis em 62 dentes. As amostras foram obtidas de 41 casos diagnosticados como periodontite apical e de 21 casos com tumefação, diagnosticados como abscesso apical agudo. Os autores encontraram $P$. gingivalis em $48 \%$ das amostras, sugerindo ser essa uma das mais patogênicas espécies presentes na cavidade oral.

Metzger et al. (2009) testaram a hipótese da adesão conjunta de F. nucleatum e $P$. gingivalis a fibroblastos humanos do ligamento periodontal em cultivo celular. A adesão de $P$. gingivalis a fibroblastos humanos aumentou quase 10 vezes quando $F$. nucleatum estava presente. Os resultados sugerem que $F$. nucleatum pode ser um colonizador primário dos tecidos do hospedeiro e servir de mediador para uma maior adesão de $P$. gingivalis para as células do hospedeiro. Isso poderia explicar em parte, a frequente ocorrência das duas bactérias nas infecções endodônticas. 
Mohammadi e Abbott (2009), em revisão, relataram o efeito antimicrobiano de substâncias irrigadoras e medicamentos utilizados atualmente no tratamento endodôntico. Várias medidas têm sido descritas para reduzir o número de microrganismos no sistema de canais radiculares, incluindo a utilização de várias técnicas de instrumentação mecânica, regimes de irrigação e medicamentos intracanal. Contudo, após a limpeza, obturação do canal, restauração temporária e restauração final, há vários períodos que podem levar o espaço do canal radicular a tornar-se infectado novamente. O hipoclorito de sódio possui muitas propriedades desejáveis, incluindo a capacidade de dissolver tecidos necróticos, bem como possuir potente ação antimicrobiana. Entretanto, não foi relatada a presença de alguma atividade antimicrobiana residual.

Ozbek et al. (2009) detectaram E. faecalis em 9 (25\%) amostras de infecções endodônticas primárias, e em 32 (74,4\%) amostras de canais com falha ao tratamento endodôntico, concluiram que esse microrganismo tem importância nas infecções endodônticas e estaria associado com às falhas de tratamentos endodônticos em adultos.

Em uma revisão sobre a diversidade da microbiota em infecções endodônticas de adultos, Siqueira e Rôças (2009) descrevem uma média de 10 a 30 espécies por canal, com predominância de anaeróbios associados, podendo os perfis bacterianos da microbiota serem diferentes entre indivíduos.

Com base na diversidade do gene $\operatorname{fim} A, P$. gingivalis é classificada em seis genótipos. Rôças e Siqueira (2010) examinaram dentes permanentes com infecções endodônticas primárias para a presença dessas variantes. Foram colhidas amostras de 25 canais radiculares de dentes com periodontite apical crônica e 25 aspirados de abscessos apicais agudos. Porphyromonas gingivalis foi detectada em $36 \%$ do número total de casos ( $44 \%$ da periodontite apical crônica e $28 \%$ da secreção do abscesso). Nos casos de periodontite apical crônica, $P$. gingivalis variante tipo IV foi o mais prevalente (24\%), seguido pelos dos tipos I (20\%), II (16\%) e III (8\%). Em amostras de abscesso agudo, o tipo II foi o mais prevalente (12\%), seguido pelos tipos III e IV (8\% cada) e tipo I (4\%). Em geral, os tipos fimA IV (16\%), II (14\%) e I $(12 \%)$ foram os mais prevalentes. Os resultados mostram que $P$. gingivalis com diferentes genótipos fimA pode estar presente em infecções endodônticas primárias. 


\subsection{Microbiota presente na polpa necrótica de dentes decíduos}

Cohen et al. (1960) realizaram análises bacteriológicas em molares decíduos necrosados de 30 crianças com 4 e 8 anos de idade. Todos mostraram destruição óssea na região entre as raízes, e em alguns casos presença de fístula. Streptococcus salivarius foi encontrado em $70 \%$, Staphylococcus epidermidis (23\%), Enterobacillus (17\%), Lactobacilos (13\%), Streptococcus mitis (10\%), Streptococcus pyogenes (10\%), Staphylococcus aureus (95\%), Neisseria catarralis (3\%) e leveduras $(3 \%)$.

Em 1967, Marsh e Largent, coletaram amostras dos canais radiculares de 18 molares decíduos que apresentavam cárie. Os mais encontrados foram Streptococcus (82\%), S. aureus e S. epidermidis (32\%), cocos e difteróides (41\%). A complexa população bacteriana detectada nesse estudo revelou que o tratamento de molares decíduos infectados deve ser direcionado para a redução ou eliminação da microbiota o mais precocemente possível.

Hobson (1970) realizou estudo cujo objetivo foi verificar as condições microscópicas da polpa e a localização de microrganismos causadores de infecções. Em 93 dentes cariados extraídos, 32 demonstraram áreas reabsorvidas na parede do canal radicular, 26 apresentavam tecido necrosado na polpa coronária e radicular, e em 18 verificou-se a penetração de cocos Gram-positivos, bacilos Grampositivos e Gram-negativos dentro dos túbulos dentinários, na região dos canais radiculares. A infiltração de microrganismos dentro dos túbulos dentinários na região do assoalho da câmara pulpar de molares sugere que toxinas possam ter acesso às áreas existentes entre as raízes, explicando a típica imagem radiolúcia encontrada em molares decíduos necrosados.

Tomić-Karović e Jelinek (1971) observaram a presença predominante de: Bacteroides spp. (36\%), Lactobacillus spp. (26\%), Streptococcus beta-hemolíticos (23\%), Streptococcus mitis e Staphylococcus spp. (20\%) e C. albicans (16\%), e concluíram que os dentes com polpas necrosadas não devem permanecer sem 0 tratamento necessário, com o intuito de preservar espaços para o sucessor permanente, tendo em vista o elevado número de patogênicos detectados. 
Ao analisar por meio de procedimentos de cultura bacteriológica a presença de microrganismos e suas enzimas na cavidade pulpar de 110 molares decíduos humanos, com infecção pulpar e ausência de lesão periapical, Edwards e Nord (1972) isolaram 96 cepas bacterianas, entre elas: Streptococcus mitis, Micrococcus spp., Peptostreptococcus spp., Enterococcus faecalis e Lactobacillus spp. Aproximadamente $19 \%$ dos isolados foram anaeróbios. Quanto à presença de enzimas, $30 \%$ dos $S$. mitis produziram hialuronidase; $E$. faecalis produziu gelatinase e atividade caseinolítica. Foi relatado que reações teciduais pulpares e periapicais dependem da associação de microrganismos capazes de elaborar reações tóxicas e imunológicas nos tecidos.

Rayner e Southam (1979) estudaram por microscopia óptica, 66 molares decíduos extraídos, sem exposição pulpar por cárie. Em 32\%, as bactérias estavam presentes na dentina tardiamente formada, e 84\% apresentaram inflamação pulpar. Isso demonstra que a dentina reacional nem sempre previne os efeitos irritativos da lesão de cárie sobre a polpa. Os resultados enfatizam a necessidade de prevenir a lesão de cárie em dentes decíduos e providenciar precocemente a restauração do elemento dentário quando necessário, tendo-se em vista a pouca espessura de dentina que recobre a polpa de dentes decíduos e, ainda, à rápida resposta da polpa frente à dentina cariada.

Brook et al. (1981) analisaram sobre condições de aerobiose e anaerobiose o conteúdo aspirado de abscessos periapicais em 12 dentes portadores de necrose pulpar em pacientes com idade entre 5 e 16 anos. Bactérias anaeróbias foram isoladas em todos os pacientes, em 8 (67\%) foram os únicos microrganismos isolados, e em 4 (33\%), estavam associados a aeróbios. Os autores concluíram que associações microbianas têm papel fundamental na etiologia de abscessos periapicais em crianças por elaborar tóxicas, com possível resistência para antimicrobianos beta-lactâmicos.

Toyoshima et al. (1988) Observaram a presença de bactérias com predomínio de bacilos Gram-negativos e Gram-positivos e cocos Gram-positivos; sendo os mais frequentes: Bacteroides, Fusobacterium, Peptostreptococcus, Streptococcus e Eubacterium. Nos espécimes onde houve o deslocamento do germe dentário do dente permanente, Bacteroides, Peptostreptococcus e Eubacterium foram 
dominantes. Isso leva a sugerir que a presença bacterina em infecções periapicais de adultos tem um papel fundamental na progressão das lesões periapicais em dentes decíduos.

Brook et al. (1991) analisaram aspirados de abscessos periapicais demostrando a predominância de Bacteroides spp., Streptococcus spp. e Fusobacterium spp. Microrganismos produtores de beta-lactamase foram também recuperados em 7 amostras. Esse estudo destaca a natureza e importância polimicrobiana de bactérias anaeróbias em abscessos periapicais e sua possível resistência aos beta-lactâmicos.

Morabito e Defabianis (1992), estudando 30 dentes decíduos extraídos, encontraram a presença de canais acessórios no assoalho pulpar em 21 deles através microscopia eletrônica de varredura. Afirmaram que o método demonstrou ser um excelente meio de avaliação, onde o insucesso do tratamento da polpa muitas vezes tem a sua causa.

Sato et al. (1993) avaliaram a composição bacteriana dos canais radiculares de 6 dentes decíduos de humanos portadores de necrose pulpar e lesões periapicais crônicas com indicação de extração. Das 276 cepas isoladas, 251 (91\%) foram anaeróbias obrigatórias, enquanto 22 (8\%) foram facultativas. Bacilos Grampositivos foram visualizados em 51\% e cocos Gram-positivos em 25\%. Os gêneros isolados com maior ocorrência foram Peptostreptococcus (25\%), Propionibacterium (19\%), Eubacterium (17\%) e Fusobacterium (13\%). Bifidobacterium (2,0\%), Lactobacillus (1,0\%), Actinomyces (1,0\%) e Veillonella (0,7\%). Salientaram que determinados microrganismos anaeróbios estão presentes tanto em canais radiculares de dentes decíduos quanto de dentes permanentes portadores de necrose pulpar e lesão periapical crônica.

A complexa morfologia e irregularidades provocadas por reabsorções fisiológicas em canais radiculares dificultam a determinação do ápice radicular no tratamento endodôntico de dentes decíduos, podendo causar insucessos. Thomas et al. (1994) realizaram estudo para avaliar a ação da pasta de iodofórmio para eliminar a infecção em casos de necrose pulpar, mostrando que o iodofórmio é adequado e 
fácil de ser utilizado para o tratamento endodôntico em dentes decíduos com infecções pulpares.

Godoy (1999) analisou a presença de bactérias em 32 dentes decíduos com polpa inflamada ou necrosada de crianças com 4 e 8 anos de idade. A avaliação em microscópio óptico evidenciou que as bactérias foram encontradas nos túbulos dentinários e no tecido pulpar na área inflamada. Em todas as amostras foram visualizadas a presença de biofilmes bacterianos, com alta prevalência de cocos e bacilos Gram-positivos, cocobacilos Gram-negativos e, menos frequentes os espirilos, localizados no exsudato, na parede dentinária interna e na área inflamada. No tecido pulpar sadio não foram vistos microrganismos. Concluindo-se que, apesar dos procedimentos e cuidados, não é possível clinicamente afirmar que todas as bactérias serão eliminadas, especialmente quando os dentes decíduos apresentamse com necrose pulpar.

Wang et al. (2000) estudaram a dentina radicular e polpas de 45 molares decíduos com cárie profunda utilizando microscopia óptica, eletrônica de varredura e cultivo. Em 95\% dos dentes, foram visualizados cocos nas paredes tubulares intactas da dentina radicular e bacilos em paredes desmineralzadas, sendo isoladas bactérias aeróbias e anaeróbias nos cultivos. Concluíram que a infecção é mista, tendo o bacilo forte poder destrutivo para os túbulos de dentina.

Önçag et al. (2003) compararam as propriedades antibacterianas e toxicidade do hipoclorito de sódio a 5,25\%, gluconato de clorexidina $2 \%$ e $0,2 \%$ e cetrimide a 0,2\%. Os irrigantes foram avaliados após 5 minutos e 48 horas, em 60 dentes permanentes recém-extraídos com raízes únicas, sendo os canais infectados por E. faecalis. Também foram coletadas 91 amostras de dentes decíduos com necrose pulpar, sendo detectados Estreptococos do grupo viridans em 61 (67,03\%) amostras, Bacteroides spp. em 36 (30,9\%), Peptostreptococcus spp. 23 (20,5\%), Veillonella spp. 18 (19,2\%), Prevotella spp. 14 (10,5\%), Fusobacterium spp. 4 (4,0\%), e Porphyromonas spp. 1 (1,1\%). Candida spp. foram isoladas em $2(2.1 \%)$ canais radiculares. Gluconato de clorexidina $2 \%$ e cetrimide foram mais efetivos contra as bactérias anaeróbias do que o hipoclorito de sódio em 48 horas. 
Pazelli et al. (2003) avaliaram a prevalência de microrganismos em 31 canais radiculares de dentes decíduos com necrose pulpar e lesão periapical crônica e concluíram a infecção, em canais radiculares de dentes decíduos portadores de necrose pulpar e lesão periapical crônica, é polimicrobiana, com prevalência de estreptococos e anaeróbios.

Faria et al. (2005), usando meios de cultura bacteriológicas, determinaram a ação antibacteriana do preparo biomecânico associado a uma solução irrigadora de hipoclorito de sódio a 2,5\% e pasta Calen (hidróxido de cálcio e oxido de zinco), utilizada como curativo de demora em 26 dentes decíduos portadores de necrose pulpar e lesão periapical. O preparo biomecânico foi eficaz na eliminação dos microrganismos dos canais radiculares em $20 \%$ dos casos e o curativo de demora em $62,5 \%$, enquanto que a ação cumulativa do preparo biomecânico e do curativo de demora eliminou os microrganismos em $70 \%$ dos casos.

Önçag et al. (2006) pesquisaram a presença de E. faecalis em 128 dentes decíduos com infecções endodônticas, avaliando também a eficácia de medicamentos usados em endodontia. Os autores isolaram a bactéria em 80 (63\%) amostras de polpas necrosadas, relacionando está ocorrência ao fato do tecido pulpar ter permanecido exposto ao meio bucal, e concluíram ser a clorexidina gel $(1 \%)$ mais eficiente contra $E$. faecalis nestas infecções.

Silva et al. (2006) analisaram 20 amostras de dentes decíduos com polpa necrosada e comprometimento ósseo visto radiograficamente na região entre as raízes. Bactérias anaeróbias foram detectadas em todas as amostras, Streptococcus spp. em 17 (85\%), sendo 6 (30\%) S. mutans. Foi concluído que em dentes decíduos humanos portadores de necrose pulpar e lesão periapical ocorrem infecções polimicrobianas, com predomínio de microrganismos anaeróbios.

Bolan e Rocha (2007) analisaram microscopicamente as características de tecidos pulpares e periapicais de 19 dentes decíduos afetados por reabsorções fisiológicas e 41 com reabsorções patológicas, determinando também a localização e intensidade da infecção bacteriana. Os dentes do grupo fisiológico estavam livres de cárie ou com cárie mínima e sem sinais ou sintomas clínicos de patologia pulpar. Já o grupo patológico era formado por dentes cariados, com alguns apresentando fístula ou abscessos. Pela técnica de coloração não foram evidenciadas células 
bacterianas no tecido pulpar. Já no grupo patológico foram visualizadas bactérias na maioria dos canais radiculares $(80,5 \%)$, sendo localizados no lúmen do canal, túbulos dentinários e parede externa das raízes. Bactérias também foram encontradas no periodonto, formando biofilmes ao lado da parede da raiz. Observaram que dentes com reabsorção patológica são reservatórios de bactérias e causadores de processos inflamatórios localizados.

Cogulu et al. (2007) investigaram a presença de E. faecalis em infecções endodônticas em 45 amostras de dentes decíduos e 38 de dentes permanentes. Foi observada a presença dessa bactéria nos canais radiculares em $22 \%$ dos dentes decíduos e $32 \%$ de permantente e isso adicionará dados sobre a presença desse microrganismo na cavidade oral, sendo importante no tratamento clínico.

Ruviére et al. (2007) pesquisaram a microbiota de canais radiculares em dentes decíduos utilizando a técnica de checkerboard em 55 canais com pulpite irreversível e em 51 canais com necrose pulpar. Observou-se elevada prevalência no primeiro grupo de Campylobacter rectus (87\%), Gemella morbilorum (78\%), Streptococcus gordonii (71\%), Capnocytophaga ochracea (69\%), Treponema denticola (58\%), e Streptococcus intermedius (49\%). No segundo grupo, C. rectus (87\%), G. morbilorum (78\%), S. gordonii (71\%), C. ochracea (69\%), T. denticola (58\%), e S. intermedius (49\%), reforçando o conhecimento de que a microbiota endodôntica é polimicrobiana e com presença de anaeróbios.

Cogulu et al. (2008a) estudaram utilizando PCR, 79 amostras de dentes decíduos e 66 de dentes permanentes portadores de infecção endodôntica em crianças da Turquia. As espécies mais prevalentes foram E. faecalis (13), $P$. gingivalis (48) e $T$. denticola (48) em dentes permanentes; e $P$. gingivalis (13) e $T$. denticola (13) em dentes decíduos. Os autores afirmaram que $E$. faecalis e $T$. denticola estão associadas à necrose pulpar em dentes decíduos e permanentes. No mesmo ano, Cogulu et al. (2008b) investigaram em crianças entre 5 e 13 anos de idade, o perfil de sensibilidade de $E$. faecalis mostrou elevada resistência à eritromicina, e sensibilidade à ampicilina, cloranfenicol, vancomicina, canamicina, meticilina, azitromicina e tetraciclina. 
Rocha et al. (2008) analisaram o terço apical da raiz de dentes decíduos extraídos de crianças entre 4 a 8 anos de idade, utilizando microscopia eletrônica de varredura. Cinco apresentavam polpa normal, sete estavam com necrose pulpar, e seis com necrose pulpar e infecção periapical. Não foram observados microrganismos nos dentes com polpa normal sem necrose pulpar. Em todos os dentes com necrose pulpar e infecção periapical, foi visualizado grande número de bactérias organizadas em biofilme na superfície radicular, sendo observados principalmente cocos e bacilos, embora espirilos e filamentos também estivessem presentes. A presença de biofilme apical em dentes decíduos pode levar à persistência do processo inflamatório, causando alterações no desenvolvimento do dente permanente sucessor, alterações do estado geral de saúde do paciente, e aceleração do processo de reabsorção fisiológica da raiz. Esses fatores podem causar a perda prematura do dente, causando sequelas estéticas e funcionais, incluindo a perda de espaço no arco e guia de erupção do sucessor permanente.

Queiroz et al. (2009) avaliaram a atividade antibacteriana de quatro materiais obturadores de canais radiculares em dentes decíduos (cimento de óxido de zinco e eugenol, pasta Calen espessada com óxido de zinco, cimento Sealapex e cimento EndoREZ) sobre bactérias comumente encontradas em infecções endodônticas: Kocuria rhizophila, E. faecalis, S. mutans, E. coli e S. aureus. Relataram que a pasta Calen, espessada com óxido de zinco, foi a mais efetiva contra E. Faecalis.

Recentemente, Yang et al. (2010), analisando aspirados de 11 abscessos de origem endodôntica em crianças, detectaram os gêneros Prevotella (24\%), Fusobacterium (17,7\%), Porphyromonas (13,9\%), Lactobacillus (11,3\%), Peptostreptococcus (8,3\%), Streptococcus (6,4\%), Eubacterium (3,8\%), Campylobacter (3,3\%), Treponema (2,6\%), mostrando que métodos moleculares, tal como PCR-DGGE, são de enorme utilidade na determinação da microbiota envolvida nesse processo. 


\section{MATERIAL E MÉTODOS}

\subsection{Pacientes e coleta de amostras}

Um total de 110 crianças com dentição decídua e com cárie foi selecionado para este estudo. As crianças pertenceram a diferentes condições sociais, e apresentaram idades entre 2 e 12 anos, sendo 69 meninos e 41 meninas, e estavam visitando as clínicas municipais da cidade de Vitória, ES, para exame oral e orientação sobre higiene dental. Todas elas apresentavam bom estado de saúde. As crianças selecionadas apresentaram cárie dental profunda, com tecido pulpar desvitalizado e exposto ao meio bucal, e em algumas delas, fístula na região gengival vestibular. Uma única amostra clínica por criança foi coletada. Crianças que tivessem feito uso de antimicrobianos nos três meses anteriores ao exame, com dentes intactos, sentindo dor na avaliação odontológica e apresentando alguma doença crônica foram excluídas.

As amostras clínicas de polpas necróticas foram coletadas de 103 crianças, sendo 35 dentes da região maxilar e 68 da mandibular. As fístulas gengivais foram coletadas de 7 crianças, 6 da região maxilar e 1 da mandibular. Todos os responsáveis pelas crianças assinaram o termo de Consentimento Livre e Esclarecido aprovado pelo Comitê de Ética em Pesquisas com Seres Humanos do Instituto de Ciências Biomédicas da Universidade de São Paulo (Proc. №. 678). A origem das amostras e número de examinados por amostras coletadas estão descritos na Tabela 1.

Na primeira avaliação clínica realizada pelo dentista responsável, os dentes e câmaras pulpares foram submetidos ao isolamento relativo com gazes esterilizadas, devido a todos os dentes apresentarem cárie profunda e exposição da polpa ao meio bucal. Em nenhum caso foram observados dentes com comprometimento pulpar e com câmara pulpar fechada. Os dentes foram desinfetados com peróxido de hidrogênio (3\%) por 1 minuto e, em seguida, com solução de hipoclorito de sódio (1\%) por 1 minuto. 
Tabela 1 - Instituições, número de crianças examinados e coleta de amostras.

\begin{tabular}{|c|c|c|c|}
\hline \multirow[b]{2}{*}{ Instituição } & \multicolumn{2}{|c|}{ Número } & \multirow[b]{2}{*}{$(\%)$} \\
\hline & Indivíduos & Amostras & \\
\hline Obra Social N.S ${ }^{a}$ das Graças & 360 & 22 & $20,00 \%$ \\
\hline Escola Cecília Meireles & 350 & 12 & $10,91 \%$ \\
\hline Escola Rubem Braga & 300 & 19 & $17,27 \%$ \\
\hline Pastoral da Criança & 150 & 19 & $17,27 \%$ \\
\hline \multicolumn{4}{|l|}{ Bairro Jucutuquara } \\
\hline Pastoral da Criança & 100 & 30 & $27,28 \%$ \\
\hline \multicolumn{4}{|l|}{ Bairro Consolação } \\
\hline Pastoral da Criança & 90 & 08 & $7,27 \%$ \\
\hline \multicolumn{4}{|l|}{ Bairro Romão } \\
\hline Pastoral da Criança & 70 & 00 & $0,0 \%$ \\
\hline \multicolumn{4}{|l|}{ Bairro Ilha Santa Maria } \\
\hline Total & 1420 & 110 & $7,74 \%$ \\
\hline
\end{tabular}

Na região da fístula, realizou-se a antissepsia com tintura de iodo (2\%) por 1 minuto. A ação do hipoclorito de sódio e tintura de iodo foi neutralizada com solução de tiossulfato de sódio (5\%), aproximadamente por 30 segundos. Nos canais radiculares que se apresentaram secos, aproximadamente uma gota de solução salina $(0,9 \%)$ esterilizada foi adicionada (Siqueira e Rôças, 2004). As coletas de material de polpa e fístulas foram realizadas utilizando-se dois cones de papel esterilizados por amostra coletada ( $n^{\circ}$ 15, Dentsply, Petrópolis, RJ, Brasil), permanecendo 1 minuto (Figuras 1 e 2). Nos molares decíduos, foram coletadas amostras de polpas em uma das raízes. As amostras coletadas foram analisadas quanto à determinação de morfotipos e extração de DNA total ao máximo de 4 horas. 


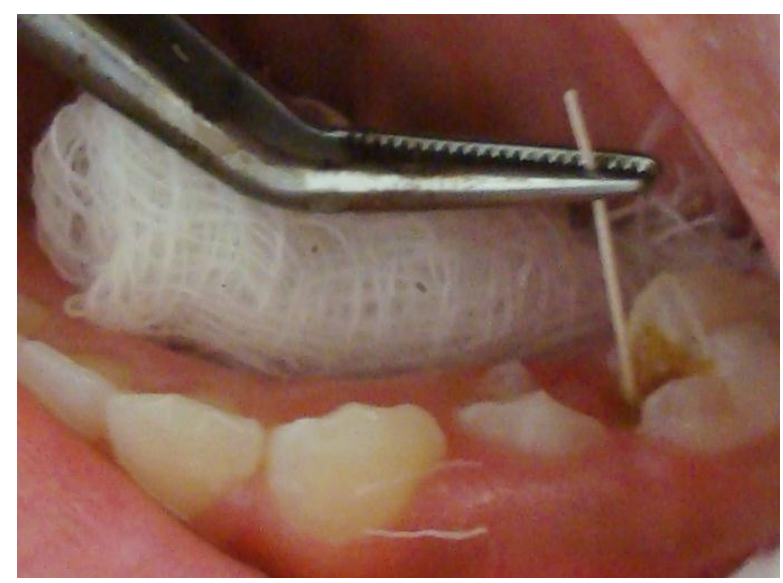

Figura 1. Coleta de amostra de polpa necrosada em segundo molar inferior esquerdo, em criança.

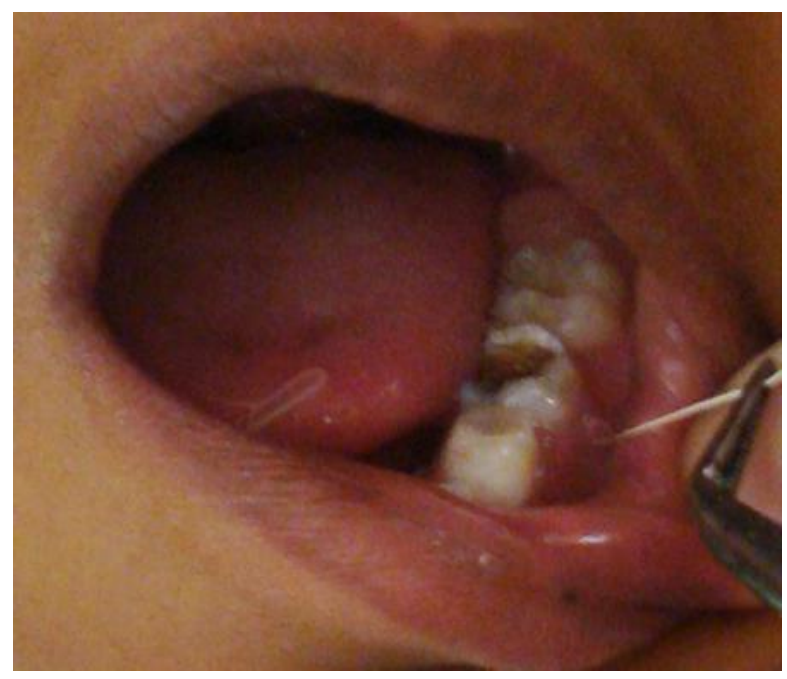

Figura 2. Coleta de amostra de fístula gengival na região do segundo molar inferior esquerdo, em criança. 


\subsection{Análise da microbiota em amostras de polpas necrosadas e fístulas}

Do material coletado, um dos cones de papel foi usado para a determinação dos diferentes morfotipos bacterianos pelas técnicas de coloração de Gram e de Brenn-Brown (Brown e Brenn, 1931; Winkler et al., 1972). Na coloração de BrennBrown, em esfregaços já fixados pelo calor, foi adicionado $1 \mathrm{ml}$ da solução $(4: 1)$ de cristal violeta (1\%) e bicarbonato de sódio (5\%) durante um minuto. Após lavagem em água corrente, foi adicionado solução de lugol (0,001\%) durante um minuto. Posteriormente, após outra lavagem em água corrente, as lâminas foram descoradas com solução de álcool-acetona (1:1). Em seguida, foi usada uma solução de fucsina básica (0,25\%), durante um minuto e, por último, adicionada $1 \mathrm{ml}$ da solução de ácido pícrico $(0,1 \mathrm{~g}$ em $100 \mathrm{ml}$ de acetona), até que ocorra uma coloração amarelada, e secagem à temperatura ambiente.

Para coloração de Gram, em esfregaço fixado pelo calor, foi colocado $1 \mathrm{ml}$ da solução de cristal violeta (1\%) por um minuto, após lavagem em água corrente, foi adicionada solução de lugol (0,001\%), durante um minuto e lavado novamente em água corrente. Posteriormente, a lâmina foi descorada com solução de álcoolacetona (1:1) por 10 segundos. E, por último, foi usado solução de fucsina básica $(0,1 \%)$ durante 30 segundos, com nova lavagem em água e secagem em papel de filtro. Os esfregaços corados foram visualizados em microscopia óptica (1000 X, Leica DMIL, Wetzlar, Germany), e documentadas com câmera de vídeo acoplada ao microscópio e computador (1000 X, Leica DMIL, Wetzlar, Germany).

O outro cone foi depositado em tubos contendo $250 \mu$ de tampão TE (10 mM Tris- $\mathrm{HCl}$ e 0.1 mM EDTA; pH, 7,3) para extração do DNA bacteriano e mantidos a $-80^{\circ} \mathrm{C}$ até o uso (Siqueira et al., 2000).

\subsection{Detecção de microrganismos na polpa e fístula}

\subsubsection{Extração do DNA total}

Cada uma das 110 amostras coletadas foi lavada três vezes por centrifugação (Eppendorf 5402, Eppendorf AG, Hamburgo, Alemanha), 2.500g, 2min; ressuspendindas em $100 \mu$ de água ultra pura esterilizada (Milli-Q, Millipore Ltda.) e fervidas por 10min. Após a centrifugação, o sobrenadante (DNA) foi estocado a -80 
${ }^{\circ} \mathrm{C}$. A concentração e a pureza do DNA foram determinadas por espectrofotômetro $\left(A_{260 n m}\right)$ e eletroforese em gel de agarose $(1 \%)$.

\subsubsection{Amplificação do DNA por PCR}

Cada reação de PCR foi realizada em volume final de $25 \mu$ l, contendo $1 \mathrm{X}$ tampão PCR (Invitrogen do Brasil, São Paulo, Brasil), 50 mM MgCl 2 (Invitrogen), 0,5 U Taq DNA polimerase (Invitrogen), $10 \mathrm{mM}$ dNTP (Invitrogen), 0,4 $\mu \mathrm{M}$ de cada iniciador, e $1 \mathrm{ng}$ DNA. As amplificações foram realizadas em termociclador (Perkin Elmer Gene Amp PCR System 2400, Norwalk, CT, EUA). Os respectivos iniciadores, ciclos de amplificação, microrganismos avaliados e produtos das reações usados na detecção, estão descritos na Tabela 2. Inicialmente, as 110 amostras foram analisadas com iniciadores universais (Amano et al., 1999) para verificar a presença de DNA bacteriano.

Os produtos de PCR foram analisados por eletroforese (70V, $2 \mathrm{~h}$ ) em gel de agarose a 1\% (Sigma Chemical Co., St. Louis, MO, USA), com tampão Tris-ácido bórico-EDTA (TBE - Invitrogen), visualizados e fotografados em transluminador com luz UV (Doc-Print II; Vilber Lourmat, Eberhardzell, Deutschland). O marcador de peso molecular utilizado foi $1 \mathrm{~kb}$ Plus DNA Ladder (Invitrogen). Em todas as reações de PCR foram usados controles negativos (água Milli $Q$ esterilizada) e DNA total de E. faecalis ATCC 29212; A. actinomycetemcomitans ATCC 29522; F. nucleatum ATCC 25586; $P$. gingivalis ATCC 33277; $P$. endodontalis ATCC 35406; $P$. intermedia ATCC 25611; $P$. nigrescens ATCC 33563; $D$. pneumosintes ATCC 33048; $T$. forsythia ATCC 43037; E. corrodens ATCC 23834; T. denticola ATCC 33520 e C. rectus ATCC 33238 como controles positivos. 
Tabela 2 - Iniciadores espécie-específico e condições de amplificação utilizadas na detecção bacteriana.

\begin{tabular}{|c|c|c|c|c|}
\hline Microrganismo & $\begin{array}{l}\text { Sequência de iniciadores } \\
\qquad\left(5^{\prime} \rightarrow 3^{\prime}\right)\end{array}$ & $\begin{array}{l}\text { Amplicom } \\
\text { bp }\end{array}$ & $\begin{array}{l}\text { Condições de } \\
\text { amplificação }\end{array}$ & Referências \\
\hline Prevotella intermedia & $\begin{array}{l}\text { TTT GTT GGG GAG TAA AGC GGG } \\
\text { TCA ACA TCT CTG TAT CCT GCG T }\end{array}$ & 600 & $\begin{array}{c}30 \text { ciclos: } 94^{\circ} \mathrm{C} / 30 \mathrm{seg}, 50^{\circ} \mathrm{C} / 30 \\
\text { seg, } 72^{\circ} \mathrm{C} / 30 \text { seg }\end{array}$ & $\begin{array}{l}\text { Ashimoto } \\
\text { et al. (1996) }\end{array}$ \\
\hline Prevotella nigrescens & $\begin{array}{l}\text { ATG AAA CAA AGG TTT TCC GGT AAG } \\
\text { CCC ACG TCT CTG TGG GCT GCG A }\end{array}$ & 804 & $\begin{array}{c}36 \text { ciclos: } 94^{\circ} \mathrm{C} / 30 \mathrm{seg}, 60^{\circ} \mathrm{C} / 1 \\
\min , 72^{\circ} \mathrm{C} / 2 \min \end{array}$ & $\begin{array}{l}\text { Ashimoto } \\
\text { et al. (1996) }\end{array}$ \\
\hline $\begin{array}{l}\text { Porphyromonas } \\
\text { endodontalis }\end{array}$ & $\begin{array}{l}\text { GCT GCA GCT CAA CTG TAG TC } \\
\text { CCG CTT CAT GTC ACC ATG TC }\end{array}$ & 672 & $\begin{array}{c}30 \text { ciclos: } 94^{\circ} \mathrm{C} / 30 \mathrm{seg}, 60^{\circ} \mathrm{C} / 30 \\
\text { seg, } 72^{\circ} \mathrm{C} / 30 \mathrm{seg}\end{array}$ & $\begin{array}{l}\text { Bogen e Slots } \\
(1999)\end{array}$ \\
\hline $\begin{array}{l}\text { Porphyromonas } \\
\text { gingivalis }\end{array}$ & $\begin{array}{l}\text { AGG CAG CTT GCC ATA CTG CG } \\
\text { ACT GTT AGC AAC TAC CGA TGT }\end{array}$ & 404 & $\begin{array}{c}30 \text { ciclos: } 94^{\circ} \mathrm{C} / 30 \mathrm{seg}, 60^{\circ} \mathrm{C} / 30 \\
\text { seg, } 72^{\circ} \mathrm{C} / 30 \mathrm{seg}\end{array}$ & $\begin{array}{l}\text { Slots et al. } \\
(1995)\end{array}$ \\
\hline Tannerella forsythia & $\begin{array}{l}\text { GCG TAT GTA ACC TGC CCG CA } \\
\text { TGC TTC AGT GTC AGT TAT ACC T }\end{array}$ & 600 & $\begin{array}{c}30 \text { ciclos: } 94^{\circ} \mathrm{C} / 30 \mathrm{seg}, 60^{\circ} \mathrm{C} / 30 \\
\text { seg, } 72^{\circ} \mathrm{C} / 30 \mathrm{seg}\end{array}$ & $\begin{array}{l}\text { Slots et al. } \\
(1995)\end{array}$ \\
\hline Fusobacterium nucleatum & $\begin{array}{l}\text { CAA ATG CTT GTG TCA ATA ATA CT } \\
\text { TTT AGA AGA AAT GGT AGA ATA AT }\end{array}$ & 500 & $\begin{array}{c}30 \text { ciclos: } 94^{\circ} \mathrm{C} / 30 \mathrm{seg}, 40^{\circ} \mathrm{C} / 30 \\
\text { seg, } 72^{\circ} \mathrm{C} / 30 \text { seg }\end{array}$ & $\begin{array}{l}\text { Avila-Campos } \\
\text { et al. (1999a) }\end{array}$ \\
\hline Treponema denticola & $\begin{array}{l}\text { TAA TAC CGA ATG TGC TCA TTT ACA T } \\
\text { TCA AAG AAG CAT TCC CTC TTC TTC TTA }\end{array}$ & 316 & $\begin{array}{c}30 \text { ciclos: } 94^{\circ} \mathrm{C} / 30 \mathrm{seg}, 60^{\circ} \mathrm{C} / 30 \\
\text { seg, } 72^{\circ} \mathrm{C} / 30 \mathrm{seg}\end{array}$ & $\begin{array}{l}\text { Slots et al. } \\
(1995)\end{array}$ \\
\hline Eikenella corrodens & $\begin{array}{l}\text { CTA ATA CCG CAT ACG TCC TAA G } \\
\text { CTA CTA AGC AAT CAA GTT GCC C }\end{array}$ & 700 & $\begin{array}{c}30 \text { ciclos: } 94^{\circ} \mathrm{C} / 30 \mathrm{seg}, 45^{\circ} \mathrm{C} / 30 \\
\text { seg, } 72^{\circ} \mathrm{C} / 30 \text { seg }\end{array}$ & $\begin{array}{l}\text { Slots et al. } \\
(1995)\end{array}$ \\
\hline Campylobacter rectus & $\begin{array}{l}\text { TTT CGG AGC GTA AAC TCC TTT TC } \\
\text { TTT CTG CAA GCA GAC ACT CTT }\end{array}$ & 600 & $\begin{array}{c}30 \text { ciclos: } 94^{\circ} \mathrm{C} / 30 \text { seg, } 50^{\circ} \mathrm{C} / 30 \\
\text { seg, } 72^{\circ} \mathrm{C} / 30 \text { seg }\end{array}$ & $\begin{array}{l}\text { Slots et al. } \\
(1995)\end{array}$ \\
\hline Enterococcus spp. & $\begin{array}{l}\text { TACTGACAAACCATTCATGATG } \\
\text { AACTTCGTCACCAACGCGAAC }\end{array}$ & 112 & $\begin{array}{c}35 \text { ciclos: } 94^{\circ} \mathrm{C} / 30 \mathrm{seg}, 50^{\circ} \mathrm{C} / 30 \\
\text { seg, } 72^{\circ} \mathrm{C} / 1 \mathrm{~min}\end{array}$ & $\begin{array}{l}\text { Ke et al. } \\
(1999)\end{array}$ \\
\hline Dialister pneumosintes & $\begin{array}{l}\text { TTC TAA GCA TCG CAT GGT GC } \\
\text { GAT TTC GCT TCT CTT TGT TG }\end{array}$ & 1105 & $\begin{array}{c}36 \text { ciclos: } 94^{\circ} \mathrm{C} / 30 \mathrm{seg}, 55^{\circ} \mathrm{C} / 1 \\
\min , 72^{\circ} \mathrm{C} / 2 \min \end{array}$ & $\begin{array}{l}\text { Doan et al. } \\
(2000)\end{array}$ \\
\hline $\begin{array}{l}\text { Aggregatibacter } \\
\text { actinomycetemcomitans }\end{array}$ & $\begin{array}{l}\text { CCG GAC GTT AGC AGG AAA TTG } \\
\text { TAA CGC CAC ATG AAA CAC TTC }\end{array}$ & 3500 & $\begin{array}{c}30 \text { ciclos: } 94^{\circ} \mathrm{C} / 30 \text { seg, } 56^{\circ} \mathrm{C} / 30 \\
\text { seg, } 72^{\circ} \mathrm{C} / 30 \text { seg }\end{array}$ & $\begin{array}{l}\text { Avila-Campos } \\
\text { et al. (1999b) }\end{array}$ \\
\hline $\begin{array}{l}\text { Iniciadores Universais } \\
16 S \text { rDNA }\end{array}$ & $\begin{array}{l}\text { AGA GTT TGA TCC TGG CTC AG } \\
\text { GGC TAC CTT GTT ACG ACT T }\end{array}$ & 3480 & $\begin{array}{c}30 \text { ciclos: } 94^{\circ} \mathrm{C} / 30 \mathrm{seg}, 58^{\circ} \mathrm{C} / 30 \\
\text { seg, } 72^{\circ} \mathrm{C} / 30 \mathrm{seg}\end{array}$ & $\begin{array}{l}\text { Amano et al. } \\
(1999)\end{array}$ \\
\hline
\end{tabular}




\section{ANÁLISE ESTATÍSTICA}

As análises estatísticas foram realizadas empregando o programa MedCalc v., 11.1 (Mariakerke, BE). Cumulative Frequency Distribution ou Frequency Table \& Chi-square test foram utilizados com o objetivo de verificar a ocorrência bacteriana em relação à idade e sexo. Valores de $P<0.05$ foram considerados estatisticamente significativos. 


\section{RESULTADOS}

Os dentes decíduos com maior ocorrência de necrose pulpar foram os molares inferiores, seguidos pelos molares superiores, caninos e incisivos. $\mathrm{Na}$ Tabela 3, podem ser observadas as características dos dentes relacionados às respectivas áreas de coletas clínicas e dentes com fístula na gengiva da região vestibular.

Tabela 3 - Características dos dentes com polpa necrosada e presença de fístulas.

\begin{tabular}{|c|c|c|c|}
\hline \multicolumn{2}{|c|}{ Região Maxilar } & \multicolumn{2}{|c|}{ Região Mandibular } \\
\hline Dente & Número (\%) & Dente & Número (\%) \\
\hline
\end{tabular}

\section{Polpa Necrosada}

$1^{\circ}$ molar direito

$10(9,7 \%) \quad 1^{\circ}$ molar direito

$16(15,5 \%)$

$1^{\circ}$ molar esquerdo

$7(6,7 \%) \quad 1^{\circ}$ molar esquerdo

$13(12,6 \%)$

$2^{\circ}$ molar direito

$3(2,9 \%) \quad 2^{\circ}$ molar direito

$19(18,5 \%)$

$2^{\circ}$ molar esquerdo

$5(4,8 \%) \quad 2^{\circ}$ molar esquerdo

$20(19,4 \%)$

Canino direito

$5(4,8 \%)$

Incisivo lateral direito

$2(1,9 \%)$

Incisivo lateral esquerdo $2(1,9 \%)$

Incisivo central direito $1(0,9 \%)$

Total

$35(33,9 \%)$

$68(66,0 \%)$

\section{Fístulas}

$1^{\circ}$ molar direito

$2(28,8 \%) \quad 1^{\circ}$ molar direito

$1(14,3 \%)$

$1^{\circ}$ molar esquerdo

$1(14,3 \%) \quad 2^{\circ}$ molar esquerdo

$1(14,3 \%)$

$2^{\circ}$ molar direito

$1(14,3 \%)$

Incisivo central direito

$1(14,3 \%)$

Total

$5(71,4 \%)$

$2(28,8 \%)$ 
A ocorrência bacteriana por grupos de idades e sexo estão descritas na Tabela 4 para amostras de polpa necrosada e fístulas.

Tabela 4 - Ocorrência bacteriana em 88 amostras clínicas de polpa necrosada e 7 de fístulas nas diferentes faixas etárias e sexo.

\begin{tabular}{lllll}
\hline & \multicolumn{4}{c}{ Idades (anos) e Sexo } \\
\cline { 2 - 5 } Microrganismo & 2 a 5 & 6 a 9 & 10 a 12 & Total \\
\cline { 2 - 3 } & M - F & M - F & M - F \\
\hline
\end{tabular}

\section{Polpas necrosadas}

$\begin{array}{lrrrr}\text { Enterococcus spp. } & 15-7 & 8-8 & 4-2 & 44 \\ \text { Porphyromonas gingivalis } & 14-4 & 9-9 & 4-3 & 43 \\ \text { Fusobacterium nucleatum } & 7-4 & 5-4 & 2-0 & 22 \\ \text { Prevotella nigrescens } & 2-0 & 0-3 & 3-2 & 10 \\ \text { Prevotella intermedia } & 1-1 & 1-1 & 1-0 & 5 \\ \text { Treponema denticola } & 1-0 & 0-2 & 0-0 & 3 \\ \text { Tannerella forsythia } & 0-0 & 0-2 & 0-0 & 2 \\ \text { Eikenella corrodens } & 0-1 & 1-0 & 0-0 & 2 \\ \text { Campylobacter rectus } & 0-0 & 0-2 & 0-0 & 2 \\ \text { Porphyromonas endodontalis } & 0-0 & 1-0 & 0-0 & 1 \\ \text { Total } & \mathbf{4 0 - 1 7} & \mathbf{2 5 - 3 1} & \mathbf{1 4}-\mathbf{7} & \mathbf{1 3 4}\end{array}$

Fístulas

\begin{tabular}{lllll} 
Enterococcus spp. & $0-0$ & $0-0$ & $1-1$ & 2 \\
Porphyromonas gingivalis & $1-0$ & $0-1$ & $1-0$ & 3 \\
Fusobacterium nucleatum & $1-0$ & $0-0$ & $0-0$ & 1 \\
Prevotella nigrescens & $0-0$ & $0-1$ & $0-0$ & 1 \\
Dialister pneumosintes & $0-0$ & $0-1$ & $0-0$ & 1 \\
Total & $\mathbf{2}-\mathbf{0}$ & $\mathbf{0}-\mathbf{3}$ & $\mathbf{2}-\mathbf{1}$ & $\mathbf{8}$ \\
\hline
\end{tabular}

M: masculino; F: feminino 
$\mathrm{Na}$ Tabela 4, pode-se observar a maior ocorrência das bactérias avaliadas, em crianças entre 2 e 5 anos de idade e do sexo masculino, mostrando valores estatisticamente diferente entre meninos da faixa etária de 6 a 9 anos $(P=0,0520)$ e de 10 a 12 anos $(P=0,0261)$.

No Gráfico 1A, são observados os diferentes morfotipos bacterianos determinados nas 110 amostras de polpas necrosadas e fístulas. Os cocos Grampositivos foram predominantes (81,8\%) em ambos os sítios (polpas e fístulas), seguidos pelos cocobacilos Gram-negativos (49,0\%) e bacilos Gram-positivos finos (15,5\%). As ocorrências de cocos Gram-positivos e cocobacilos Gram-negativos não foram estatísticamente diferente entre os sexos ( $P=0,4260$, cocos Gram-positivos e $P=0,4386$, cocobacilos Gram-negativos), ou idades ( $P=0,2625$, cocos Grampositivos e $P=0,7380$, cocobacilos Gram-negativos). No Gráfico 1B observa-se a distribuição de morfotipos em associações.

Com a utilização dos iniciadores universais nas reações de PCR, das 110 amostras de DNA, somente 88 de polpas necróticas e 7 de fístulas apresentaram DNA bacteriano. Nas 15 amostras não amplificadas, é possível que tenha ocorrido degradação ou presença de poucas cópias de DNA.

No Gráfico 2A, pode se observar que Enterococcus spp. (50\%), P. gingivalis $(48,9 \%)$ e F. nucleatum (25\%), foram predominantes em amostras de polpas necrosadas. A ocorrência de Enterococcus spp. foi estatíticamente diferente $(P=$ 0,0297), sendo maior em meninos que meninas, não se observando diferenças significativas em relação as idades $(P=0,2994)$. Da mesma forma, não foram observadas diferenças na ocorrência de $P$. gingivalis entre os parâmetros sexo e idade $(P=0,2994$ e $P=0,3299)$, respectivamente. Em nenhuma amostra clínica de polpa necrosada foi detectada a presença de $A$. actinomycetemcomitans e $D$. pneumosintes. No gráfico 2B observam-se as associações bacterianas.

Em 7 amostras de fístulas foram detectados $P$. gingivalis (43\%), Enterococcus spp. $(28,6 \%)$, F. nucleatum (14,3\%), P. nigrescens $(14,3 \%)$ e D. pneumosintes (14,3\%). Em 2 fístulas, $P$. gingivalis foi detectado associado com Enterococcus spp. e $F$. nucleatum, e $P$. nigrescens associado a $D$. pneumosintes. Não foram encontradas bactérias nas outras duas fístulas analisadas. 


\section{MORFOTIPOS ENCONTRADOS}

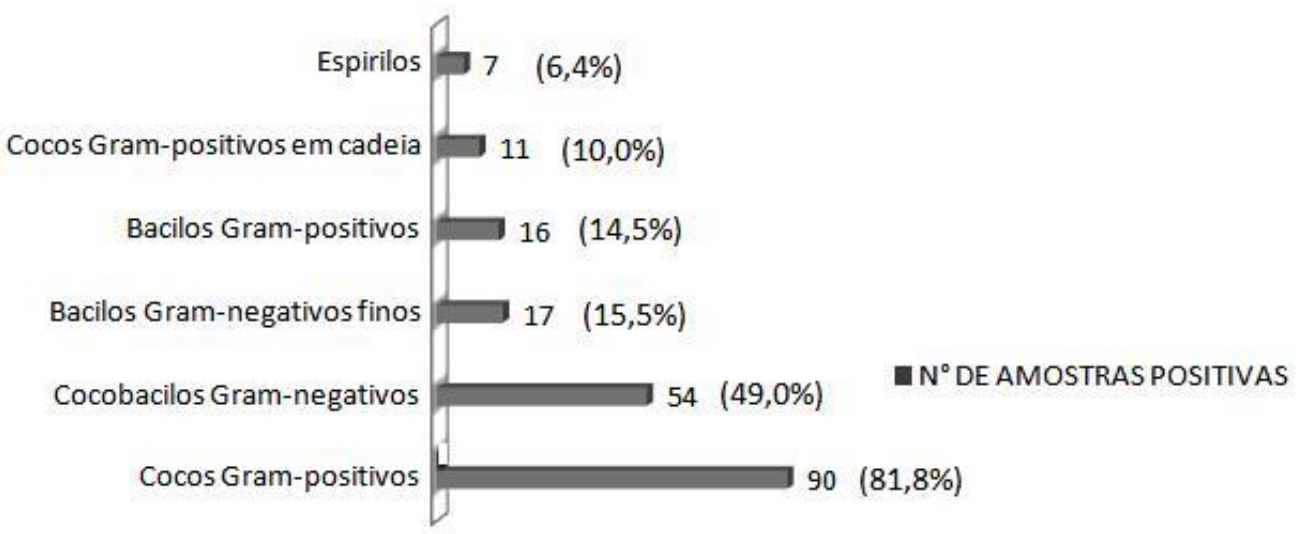

(A)

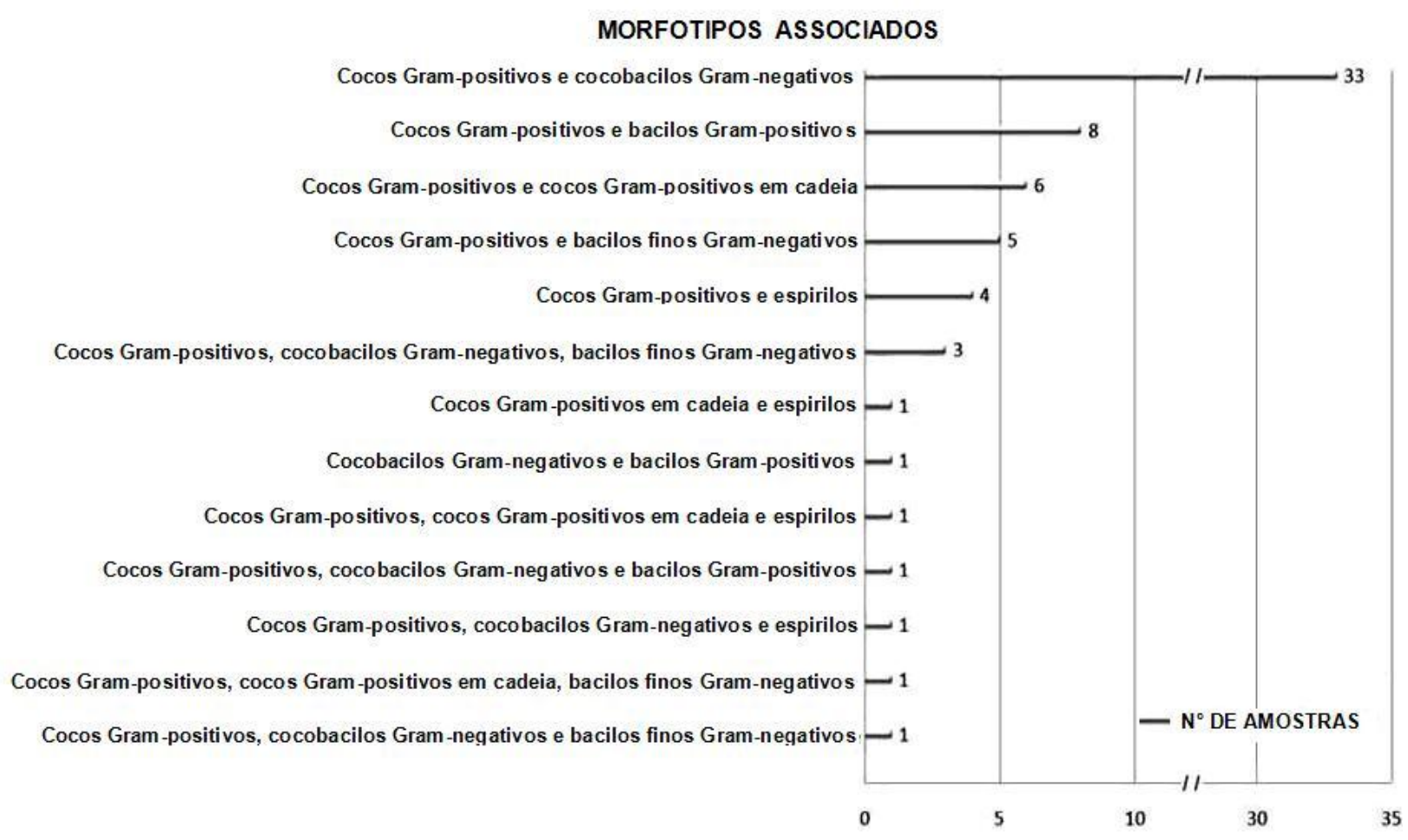

(B)

Figura 3. Morfotipos bacterianos observados nas amostras de polpa necrosada e fístulas analisadas pelas colorações de Gram e Brenn-Brown (A). Associações de morfotipos bacterianos (B). 


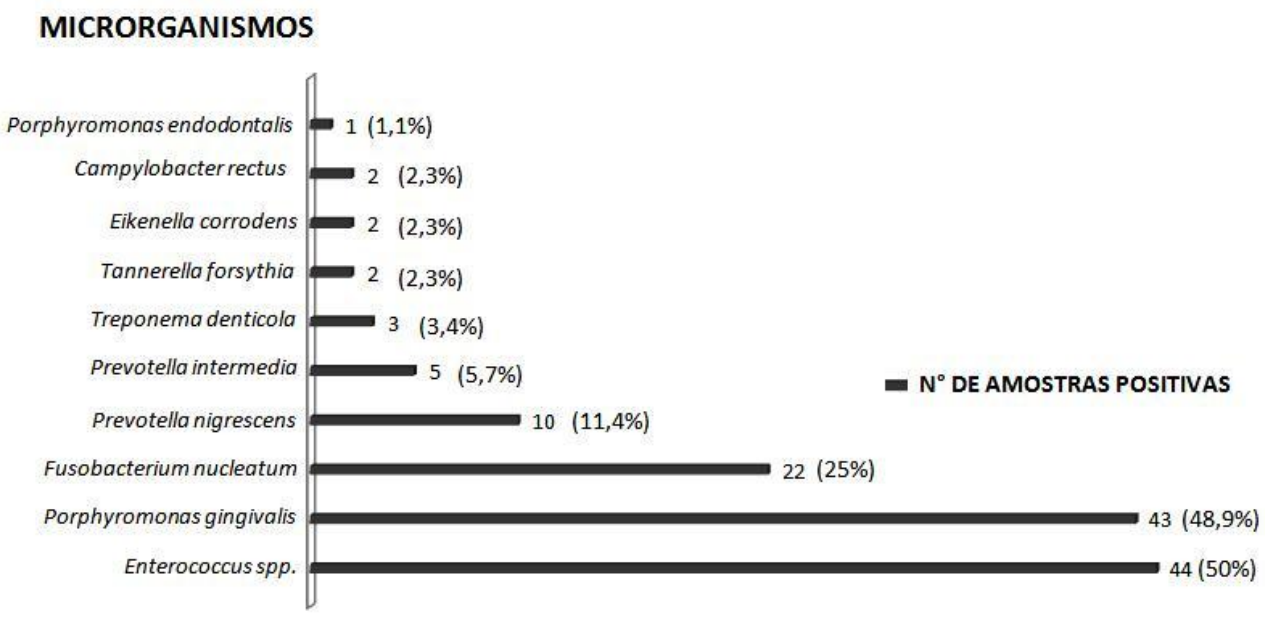

\section{MICRORGANISMOS ASSOCIADOS}

C. rectus, T. forsythia, P. intermedia, P. gingivalis, Enterococcus spp.

Tannerella forsythia, P. nigrescens, $P$. gingivalis, Enterococcus spp. Prevotella nigrescens, P. intermedia, P. gingivalis, Enterococcus spp. Treponema denticola, P. intermedia, P. gingivalis, Enterococcus spp.

Prevotella nigrescens, Fusobacterium nucleatum, P. gingivalis Porphyromonas endodontalis, Porphyromonas gingivalis Eikenella corrodens, F. nucleatum, P. gingivalis Treponema denticola, P. gingivalis, Enterococcus spp Porphyromonas gingivalis, Prevotella intermedia Porphyromonas gingivalis, Prevotella nigrescens

F. nucleatum, P. nigrescens, Enterococcus spp. Fusobacterium nucleatum, Prevotella nigrescen Fusobacterium nucleatum, Enterococcus spp. Fusobacterium nucleatum, P. gingivalis, Enterococcus spp. Porphyromonas gingivalis, Enterococcus spp.

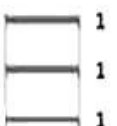
$\longrightarrow$
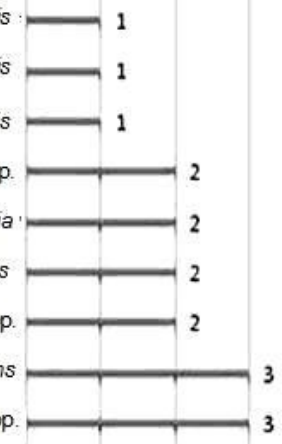

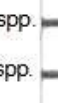

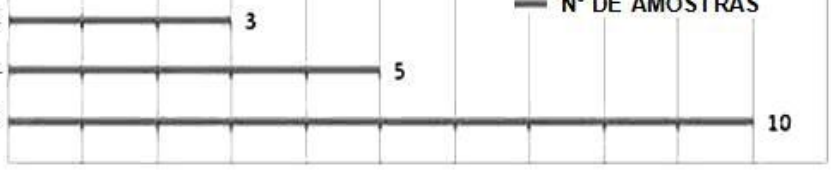

01 2 4 5 6

Figura 4. Detecção bacteriana por PCR em 88 amostras clínicas de polpa necrosada de dentes decíduos. (A) bactérias detectadas individualmente, e (B) bactérias detectadas em associações. 


\section{DISCUSSÃO}

Neste estudo, os dentes cariados com maior ocorrência de polpas necrosadas foram os molares decíduos inferiores, seguidos pelos molares superiores. Provavelmente por ocorrer maior retenção de alimentos, principalmente carboidratos, que muitas vezes são consumidos de forma descontrolada nessas faixas etárias, e maior formação de placa bacteriana, associados a uma higiene oral deficiente (Reisine e Psoter, 2001; Braga et al., 2010), esses dentes tornam-se geralmente mais susceptíveis ao desenvolvimento de cárie dental oclusal e conseguente comprometimento pulpar. Foi observado, principalmente nas crianças de 10 a 12 anos de idade, que os molares decíduos com necrose apresentavam raízes pouco reabsorvidas. Provavelmente, a necrose pulpar poderia ter influenciado o atraso da reabsorção e consequente troca dos dentes. Por outro lado, é importante lembrar que, essa pequena reabsorção radicular é influenciada por fatores hormonais, traumas e infecções (Gorski e Marks, 1992; Rimondini e Baroni, 1995; Harokopakis-Hajishengallis, 2007).

A ocorrência de morfotipos bacterianos tem sido descrita em infecções endodônticas primárias de adultos, representados por cocos, bacilos, formas filamentosas e espirilos (Miller, 1894; Boyle, 1934; Brown e Rudolph, 1957; Winkler et al., 1972; Nair, 1987; Nair et al., 1990; Tronstad et al., 1990; Siqueira et al., 2002). Em crianças com infecções bucais como a cárie, acompanhado de processo pulpar, a ocorrência de morfotipos é observada (Marsh e Largent, 1967; Hobson, 1970; Toyoshima et al., 1988; Sato et al, 1993; Godoy, 1999; Wang et al., 2000; Rocha et al., 2008). Bactérias presentes na placa bacteriana aderida ao esmalte da coroa dental e sulco gengival invadem o tecido pulpar através da cárie e reabsorções fisiológicas das raízes, que ocorrem em muitos períodos da dentição (Fanning, 1962; Rimondini e Baroni, 1995; Harokopakis-Hajishengallis, 2007).

Cocos Gram-positivos e cocobacilos Gram-negativos conseguiram se adaptar melhor na polpa necrosada e fístula, proporcionando também, a colonização de outros morfotipos visualizados neste estudo, interagindo sinergisticamente no tecido infectado. Associações bacterianas de diferentes morfotipos podem ocorrer em biofilmes da superfície radicular do dente decíduo e em fístulas, principalmente em áreas de reabsorções, causando a continuidade do processo infeccioso (Bolan e 
Rocha, 2007; Rocha et al., 2008). A falta de tratamento da infecção endodôntica pode acarretar alterações no desenvolvimento do dente permanente sucessor, e no processo de reabsorção da raiz, levando à perda prematura do dente decíduo.

Espécies bacterianas dos gêneros Prevotella, Porphyromonas, Fusobacterium, Treponema, Campylobacter, Enterococcus, Tannerella, Dialister e Streptococcus, têm sido identificadas em infecções endodônticas primárias de adultos. (Kantz e Henryum, 1973; Sundqvist, 1992; Sundqvist, 1994; Conrads et al., 1997; Siqueira et al., 2000; Rôças et al., 2003, Rôças e Siqueira, 2006b; Tomazinho e Avila-Campos, 2007; Jacinto et al., 2008; Pirani et al., 2008; Ozbek et al., 2009; Siqueira e Rôças, 2009).

Enterococos constituem parte da microbiota residente intestinal, trato genital e cavidade bucal, podendo causar uma variedade de infecções no trato urinário, na região intra-abdominal e pélvica, produzindo bacteremias e endocardite, e em infecções dos tecidos moles e infecções endodônticas. As publicações descrevem que $90 \%$ das infecções produzidas por enterococos em adultos são causadas principalmente pelo E. faecalis, seguida pelo E. faecium (Ke et al., 1999; Kayaoglu e Ørstavik, 2004; Sedgley et al., 2006).

A presença desses microrganismos em vários sítios da cavidade oral tem como provável acesso à polpa pelo processo carioso, que expõem o tecido pulpar e a dentina radicular ao meio bucal, favorecendo a sua colonização, e manutenção utilizando o ácido hialurônico, produto de degradação dentinária, componentes do soro presentes em tubulos dentinários, ou por produtos metabólicos de outras bactérias (Fabricius et al., 1982; Sobrinho et al., 1998; Peciuliene et al., 2001).

Utilizando-se o PCR com iniciadores específicos na detecção de Enterococcus spp. que, de acordo com Nandakumar et al. (2007), é o método mais sensível na detecção de $E$. faecalis em canal radicular, observamos o microrganismo em $50 \%$ das amostras de polpa, com maior ocorrência em crianças do sexo masculino, notando-se diferenças em relação às infecções que ocorrem em adultos, onde enterococos têm ocorrido entre 9 a 18\% nas infecções primárias, sendo considerada uma baixa proporção, principalmente se comparada com os dados obtidos neste trabalho. Entretanto, a literatura descreve a presença desse 
microrganismo variando de $18 \%$ a $82 \%$, de forma individual ou em associação com outras bactérias (Pinheiro et al., 2003; Rôças et al., 2004; Gomes et al., 2006). Além disso, Enterococcus spp. foram encontrados não associados em 19\% das amostras pulpares, levando a uma dificuldade do tratamento endodôntico, o que favorece para a progressão da doença em sua forma crônica (Sundqvist et al., 1998; Sedgley et al., 2006; Stuart et al., 2006; Pirani et al., 2008; Ozbek et al., 2009).

Uma hipótese para explicar esta proporção de Enterococcus spp. em nossas amostras de polpas, poderia ser a utilização do microrganismo pela indústria de alimentos brasileira. Por outro lado, Gomes et al. (2008) encontraram espécies de Enterococcus em $52,5 \%$ de alimentos lácteos, como leite e queijos que são diariamentes consumidos pelas crianças. No estudo, os autores sugerem que o consumo diário dos alimentos que contêm enterococos, poderia colaborar com 0 aumento desse microrganismo nos processos cariosos com polpa necrosada nessa faixa etária, entretanto, isso não está totalmente definido. Recentemente, Vidana et al. (2011) analisaram por eletroforese de campo pulsado (PFGE) E. faecalis isolados de canal radicular necrosado e material fecal de pacientes adultos com infecção endodôntica, sem observar alguma semelhança genética entre eles; concluindo que a origem dessa bactéria seria exógena.

Estudos realizados em infecções de polpas de dentes decíduos são escassos, entretanto, os únicos trabalhos neste sentido foram realizados em população infantil da Turquia, observando-se uma ocorrência bacteriana que varia de 13 a $63 \%$ (Önçag et al., 2006; Cogulu et al., 2007; Cogulu et al., 2008a). Apesar de os resultados desses autores serem similares aos que se encontram neste trabalho, seriam importantes maiores pesquisas em diferentes faixas etárias em nosso País como em outros. Isso seria importante devido à resistência que essa bactéria pode adquirir contra os antimicrobianos utilizados no tratamento endodôntico (Önçag et al., 2003; Cogulu et al., 2008b, Queiroz et al., 2009)

Bacilos produtores de pigmento negro, pertencentes aos gêneros Prevotella e Porphyromonas, têm sido associados a infecções pulpares primárias e abscessos perirradiculares agudos (Sundqvist et al., 1989; Sundqvist, 1992; van Winkelhoff et al., 1992; Siqueira e Rôças, 2009). Embora pertençam à microbiota do sulco gengival e bolsas periodontais, têm sido relatadas similaridades com a microbiota endodôntica, indicando a possibilidade de infecções entre o canal radicular e bolsa 
periodontal de adultos (Moore et al., 1985; Kerekes e Olsen, 1990). As possíveis vias de acesso à polpa ocorrem através de canais acessórios presentes no assoalho da câmara pulpar, dentina e cemento com permeabilidade alterada na presença de infecção, ou as áreas de reabsorções fisiológicas da raiz (Moss et al., 1965; VermotGaud, 1967; Morabito e Defabianis, 1992).

A presença de $P$. gingivalis em dentes decíduos ocorre de 1 e $27 \%$ (Önçag et al. 2003; Ruviére et al., 2007; Cogulu et al., 2008a; Yang et al., 2010). Entretanto, os resultados apresentados neste estudo mostram a ocorrência dessa bactéria (49\%) similar com aquela obtida em indivíduos adultos (10 e 43\%) (Siqueira et al., 2001; Siqueira e Rôças, 2008; Tomazinho e Avila-Campos, 2007). van Winkelhoff et al. (1987) descreveram um sinergismo negativo entre espécies produtoras de pigmento negro. Porphyromonas gingivalis possui uma maior capacidade inibitória, sendo sempre dominante, com percentual significativamente maior em relação a outras espécies, ocorrendo algumas vezes como monoinfecção em abscessos e polpas. Em 17\% das amostras de polpas examinadas, essa bactéria foi encontrada como a única espécie, isso, provavelmente seja devido à inibição entre espécies.

Em adição, a presença de $P$. nigrescens, $P$. intermedia e $P$. endodontalis foi menor (Amano et al., 1999; Siqueira et al., 2001; Siqueira e Rôças, 2009). Prevotella intermedia e $P$. nigrescens participam de infecções mistas, sendo a primeira frequentemente associada à doença periodontal, e a segunda às infecções endodônticas (Sundqvist, 1992; Wayman et al., 1992; Gharbia et al., 1994; Ashimoto et al., 1996; Fouad et al., 2002; Tomazinho e Avila-Campos, 2007).

Em nosso estudo, essas espécies bacterianas foram observadas entre 5 a $11 \%$ das amostras de polpa avaliadas, semelhante aos resultados descritos por outros autores (Önçag et al. 2003; Ruviére et al., 2007; Cogulu et al., 2008a; Yang et al., 2010). Também, elas foram associadas a outras bactérias aqui detectadas, sugerindo-se que essa associação bacteriana possa contribuir para a patogenicidade e manutenção do processo infeccioso.

Associações foram detectadas entre espécies dos gêneros Prevotella e Porphyromonas com outras bactérias e principalmente com Enterococcus spp., relação ainda não descrita por outros autores. A disponibilidade de nutrientes, baixas 
tensões de oxigênio em canais radiculares com necrose pulpar e interações bacterianas são importantes determinantes ecológicos (Sundqvist et al., 1989; Sundqvist, 1992). Contudo, aparentemente $P$. gingivalis e Enterococcus spp. conseguiram se adaptar ao tecido pulpar necrótico, individualmente ou associados, podendo ocasionar danos aos tecidos vizinhos, como o germe dentário do dente permanente em formação, devido ao processo infeccioso crônico, dificultando também o tratamento endodôntico.

Fusobacterium nucleatum coloniza a cavidade bucal, sendo comumente isolado de infecções orais (Bolstad et al., 1996; Avila-Campos et al., 1999a). Estudos têm mostrado uma prevalência entre 34 e $48 \%$ em infecções endodônticas primárias de adultos (Sundqvist et al., 1989; Wayman et al., 1992; Sundqvist, 1992; Jacinto et al., 2008). Em polpas de dentes decíduos, é descrita uma ocorrência menor da bactéria, entre 4 e 18\% (Sato et al., 1993; Önçag et al., 2003; Yang et al., 2010). Simliar a esses resultados, F. nucleatum foi encontrada em $25 \%$ das polpas analisadas, sendo o único microrganismo em $9 \%$ delas, ocorrendo associado principalmente a Enterococcus spp. e P. gingivalis. (Johnson et al., 2006; Saito et al., 2008).

Associação sinergística entre $F$. nucleatum e $P$. gingivalis tem sido descrita em diversas formas de periodontites (Bolstad et al., 1996), sendo observada a formação de biofilmes significativos (Saito et al., 2008; Metzger et al., 2009). As amostras de polpas e fístula apresentaram essas bactérias, o que provavelmente favorece a formação de biofilmes nos tecidos, contribuindo para a persistência do processo inflamatório, o que em alguns casos mais severos, poderia ocasionar alterações estéticas e funcionais indesejáveis (Rocha et al., 2008).

Espiroquetas presentes na microbiota oral foram detectadas por métodos moleculares de infecções endodônticas primárias de adultos (entre 9 e $77 \%$ ), sendo mais predominantes $T$. denticola e T. socranskii (Siqueira et al., 2000; Rôças et al., 2003; Siqueira e Rôças, 2003a). Em infecções de polpas de dentes decíduos, é descrita a ocorrência de 2,6\% para Treponema spp. (Yang et al., 2010). No interior do canal radicular (Rôças e Siqueira, 2010), há participação na ligação entre os colonizadores pioneiros e tardios, tais como $P$. gingivalis detectada em quase $50 \%$ das amostras de polpas, que juntamente com Treponema spp. são considerados 
microrganismos importantes na doença periodontal de adultos. Apesar de $T$. denticola ter sido detectado em pequena proporção nas amostras de polpa, foi observada a associação com $P$. gingivalis, Enterococcus spp. e $P$. nigrescens. Esses microrganismos associados também poderiam favorecer a implantação dessas espiroquetas e outros colonizadores tardios no tecido pulpar necrosado, contribuindo para formação de biofilmes patogênicos, com acesso à região gengival e do dente permanente em formação, prolongando o processo infeccioso.

Tannerella forsythia, Campylobacter rectus e Eikenella corrodens, ocorrem em infecções endodônticas primárias de adultos em baixa frequência (Chen e Wilson, 1992; Wayman et al., 1992; Conrads et al., 1997; Siqueira e Rôças, 2003b; Rôças e Siqueira, 2006a; Siqueira e Rôças, 2009). Cada uma das três espécies foi detectada em $2,3 \%$ das amostras de polpas, proporção similar às infecções de adultos. $T$. forsythia e $C$. rectus, ainda não relatados em polpas em dentes decíduos, ocorreram somente em amostras coletadas de crianças do sexo feminino, entre 6 a 9 anos de idade, estando associadas principalmente a Enterococcus spp. e $P$. gingivalis, agentes que podem contribuir para a implantação desses dois colonizadores tardios no biofilme microbiano. Semelhantemente aos resultados apresentados nesta pesquisa, recentemente, Yang et al. (2010) detectaram Campylobacter spp. em 3,3\% das amostras de abscessos de origem endodôntica em crianças.

Eikenella corrodens pode ser considerado o único agente infeccioso ou parte de uma infecção mista (Chen e Wilson, 1992), observando-se associada a $P$. gingivalis e $F$. nucleatum, colaborando com o processo infeccioso de forma crônica. Esse microrganismo tem apresentado uma prevalência média de $18 \%$ em infecções endodônticas de adultos (Rôças e Siqueira, 2006a). Diferentemente, Ruviére et al. (2007) não observaram o microrganismo nas 106 amostras de polpas analisadas.

Dialister pneumosintes ocorre em sítios do sulco gengival de crianças e adultos jovens com gengivite e periodontite, podendo causar infecções em vários locais do corpo humano, incluindo pulmão, cérebro e também em canais radiculares (Doan, 2000). Essa espécie tem sido descrito nas infecções endodônticas primárias, mas em pequena proporção, associado às lesões periapicais em adultos (Siqueira e Rôças, 2004; Rôças e Siqueira, 2006b; Siqueira e Rôças, 2009). Em nosso estudo, 
esse microrganismo foi detectado em apenas uma amostra de fístula, conseguindo se associar a $P$. nigrescens. É importante salientar que a presença de $D$. pneumosintes ou a associação com outras bactérias não é observada na literatura, principalmente em dentes decíduos ou fístulas de crianças.

Aggregatibacter actinomycetemcomitans não foi detectado nas amostras analisadas. Apesar de possuir importantes fatores de virulência, e estar relacionada à etiologia da periodontite agressiva em indivíduos jovens (Moore et al., 1985; AvilaCampos et al., 1999b; Fabris et al., 2002), a bactéria provavelmente não consegue se adaptar e colonizar o ambiente do canal radicular (Sundqvist, 1992). Recentemente, Sakai et al. (2007) estudaram no Brasil a ocorrência de periodontopatógenos na saliva de 64 crianças saudáveis, relatando a presença de $A$. actinomycetemcomitans em somente quatro amostras analisadas.

A conservação da dentição decídua no seu estado funcional até a esfoliação fisiológica tem sido o objetivo da Odontopediatria. Quando dentes decíduos apresentam inflamação pulpar irreversível ou necrose, acompanhada algumas vezes de fístula gengival, decorrentes de cárie dental ou traumatismos, e sendo possível sua manutenção no arco dentário, o tratamento endodôntico será indicado (Cuoghi et al., 1998; Thilander, 2009; Cooper et al., 2010).

Durante décadas, o tratamento endodôntico de dentes decíduos foi realizado de forma empírica, simplesmente para eliminar a dor e controles dos processos patológicos em nível clínico. Vários autores preconizam que em dentes decíduos cariados com envolvimento pulpar, o tratamento endodôntico deve ser aplicado visando eliminar as bactérias presentes no interior dos canais radiculares (Cohen et al., 1960; Marsh e Largent, 1967; Tomić-Karović e Jelinek, 1971; Rayner e Southam, 1979; Card et al., 2002; Bolan e Rocha, 2007; Rocha et al., 2008). Por outro lado, apesar de vários estudos, até o momento não se observam protocolos padronizados de tratamento clínico, sendo utilizadas técnicas de instrumentação do canal, assim como o uso de soluções irrigadoras de hipoclorito de sódio, cimentos à base de hidróxido de cálcio e óxido de zinco eugenol (Faria et al. 2005; Reddy e Ramakrishna, 2007; Dunston e Coll, 2008; Mohammadi e Abbott, 2009). 
Alguns estudos têm descrito a relação de $E$. faecalis com o provável insucesso em tratamentos endodônticos de adultos, particularmente devido à sua resistência a cimentos à base de hidróxido de cálcio e soluções irrigadoras usadas no tratamento (Möller, 1966; Lin, 1991; Sundqvist et al., 1998; Hancock et al., 2001; Rôças et al., 2004; Gomes et al., 2006; Önçag et al., 2006; Reddy e Ramakrishna, 2007; Mohammadi e Abbott, 2009; Queiroz et al., 2009). Essa resistência também pode ocorrer na terapêutica de dentes decíduos, ocasionando a persistência da infecção. A sobrevivência ao hidróxido de cálcio parece estar relacionada à síntese de proteínas induzidas pelo estresse, além de uma bomba de prótons de membrana, essencial para a sua permanência em pH elevado (Evans et al., 2002). De forma similar, $P$. gingivalis consegue também invadir túbulos dentinários radiculares (Siqueira et al., 1996), ficando protegida da ação dos antimicrobianos usados na clínica.

Kishen et al. (2008) destacaram que algumas substâncias químicas usadas no tratamento endodôntico, podem alterar as propriedades físico-químicas da dentina, influenciando a natureza de adesão, a força de aderência e formação de biofilme bacteriano na dentina.

Aderência às superfícies dos canais radiculares por bactérias para formar biofilmes tem sido um bom exemplo de mecanismo de adaptação para colonização e sobrevivência (Sundqvist, 1992; Godoy, 1999; Bolan e Rocha, 2007; Rocha et al., 2008). E. faecalis, P. gingivalis, F. nucleatum e $P$. intermedia, são capazes de aderir ao colágeno tipo I e IV (Naito e Gibbons, 1988; Grenier 1996; Kayaoglu e Ørstavik, 2004; Kishen et al., 2008; Saito et al., 2008). Além do colágeno tipo I, presente na dentina dos dentes permanentes, a dentina do dente decíduo também apresenta 0 tipo IV (Linde, 1985; Agematsu et al., 1997). Esses microrganismos foram observados em maior proporção neste estudo, e como o dente decíduo também apresenta colágeno na dentina radicular e polpa, a adesão e consequente colonização seriam facilitadas nesses dentes, contribuindo para a manutenção da infecção na sua forma crônica (Wayman et al., 1992), e consequente comprometimento dos tecidos vizinhos, como a região periapical e germe dentário do dente permanente em formação. 
A literatura tem descrito os microrganismos encontrados nos canais de dentes decíduos como sendo similares àqueles de canais radiculares dos dentes permanentes (MacDonald et al., 1957; Marsh e Largent, 1967; Tomić-Karović e Jelinek, 1971; Edwards e Nord, 1972). Porém, as ocorrências de Enteroccocus spp. e $P$. gingivalis em nossas amostras de polpas avaliadas diferiram dos relatos para infecções endodônticas primárias em dentes permanentes de adultos, onde as descrições foram menores para as duas bactérias (Sundqvist, 1992; Gomes et al., 2006; Sedgley et al., 2006; Siqueira e Rôças, 2008; Ozbek et al., 2009; Rôças e Siqueira, 2010).

Os resultados deste estudo mostraram que nas infecções de polpa em dentes decíduos é observada uma grande variedade de bactérias, refletindo um possível sinergismo estabelecido no interior do canal, caracterizando uma infecção polimicrobiana e com predominância de Enterococcus spp. e P. gingivalis.

Apesar dos procedimentos e cuidados técnicos adotados com a evolução dos medicamentos utilizados, a presença de Enterococcus spp. no interior do canal radicular de dentes decíduos deve ser considerada pelo clínico quando o tratamento endodôntico for necessário, uma vez que essa bactéria pode se tornar resistente às substâncias antimicrobianas utilizadas na clínica odontopediátrica. 


\section{CONCLUSÕES}

Após a análise dos resultados obtidos, pode-se concluir que:

1. Cocos Gram-positivos foram predominantes em relação aos cocobacilos Gramnegativos, entretanto, as associações desses dois morfotipos foram comumente observadas;

2. Enterococcus spp. e $P$. gingivalis foram os mais predominantes nas amostras clínicas de polpa e fístulas; e

3. Associações bacterianas foram frequentemente observadas em ambos os casos clínicos que afetaram as crianças examinadas. 


\section{REFERÊNCIAS}

Akpata ES, Blechman H. Bacterial invasion of pulpal dentin wall in vitro. J Dent Res. $1982 ; 61(2): 435-8$.

Agematsu H, Sawada T, Watanabe H, Yanagiisawa T, Ide Y. Immuno-scanning electron microscope characterization of large tubules in human deciduous dentin. Anat Rec. 1997;248:339-45.

Amano A, Nakagawa I, Kataoka K, Morisaki I, Hamada S. Distribution of Porphyromonas gingivalis strains with fimA genotypes in periodontitis patients. J Clin Microbiol. 1999;37:1426-30.

Ashimoto A, Chen C, Bakker I, Slots J. Polymerase chain reaction detection of 8 putative periodontal pathogens in subgingival plaque of gingivitis and advanced periodontitis lesions. Oral Microbiol. Immunol. 1996;11:266-73.

Avila-Campos MJ, Sacchi CT, Whitney AM, Steigerwalt AS, Mayer LW. Arbitrarily primed-polymerase chain reaction for identification and epidemiologic subtyping of oral isolates of Fusobacterium nucleatum. J Periodontol. 1999a;70:1202-8.

Avila-Campos MJ, Sacchi CT, Whitney AM, Steigerwalt AS, Mayer LW. Specific primer for AP-PCR identification of Actinobacillus actinomycetemcomitans. J Clin Periodontol. 1999b;26:699-704.

Avila-Campos MJ, Velásquez-Meléndez G. Prevalence of putative periodontopathogens from periodontal patients and healthy subjects in São Paulo, SP, Brazil. Rev Inst Med Trop S Paulo. 2002;44:1-5.

Barnett EM, Mehta JD. Oral growth stages--the keys to guiding occlusal development. J Am Dent Assoc. 1970;81(6):1360-8.

Baroni C, Rimondini L. Space maintenance and endodontic follow-up: case reports. J Clin Pediatr Dent. 1992;16(2):94-7.

* De acordo com: International Committee of Medical Journal Editors. Uniform requirements for manuscripts submittedto Biomedical Jounal: sample references. Available from: http://www.icmje.org [2007 May 22]. 
Bolan M, Rocha MJC. Histopathologic study of physiological and pathological resorptions in human primary teeth. Oral Surg Oral Med Oral Pathol Oral Radiol Endod. 2007;104:680-5.

Bolstad Al, Jensen HB, Bakken V. Taxonomy, biology, and periodontal aspects of Fusobacterium nucleatum. Clin Microbiol Rev. 1996;9(1):55-71.

Bogen G, Slots J. Black-pigmented anaerobic rods in closed periapical lesions. Int Endod J. 1999;32(3):204-10.

Boyle PE. Intracellular bacteria in a dental granuloma. J Dent Res. 1934;14(4):297301.

Braga MM, Martignon S, Ekstrand KR, Ricketts DN, Imparato JC, Mendes FM. Parameters associated with active caries lesions assessed by two different visual scoring systems on occlusal surfaces of primary molars a multilevel approach. Community Dent Oral Epidemiol. 2010;38(6):549-58.

Brasil. Ministério da Saúde. Secretaria de Atenção à Saúde. Departamento de Atenção Básica. Projeto SB Brasil 2003: condições de saúde bucal da população brasileira 2002-2003. Resultados principais. Brasília: Ministério da Saúde. 2004.

Brook I, Grimm S, Kielich RB. Bacteriology of acute periapical abscess in children. J Endod. 1981;7:378-80.

Brook I, Frazier EH, Gher ME. Aerobic and anaerobic microbiology of periapical abscess. Oral Microbiol Immunol. 1991;6(2):123-5.

Brook I. Microbiology and management of endodontic infections in children. J Clin Pediatr Dent. 2003;28(1):13-7.

Brown JH, Brenn L. A method for the differential staining of Gram-positive and Gramnegative bacteria in tissue sections. Bull Johns Hopk. 1931;48:69-73.

Brown LR, Rudolph CE. Isolation and identification of microorganisms from unexposed canals of pul-involved teeth. Oral Surg Oral Med Oral Pathol. 1957; 10(10):1094-9. 
Card SJ, Sigurdsson A, Orstavik D, Trope M. The effectiveness of increased apical enlargement in reducing intracanal bacteria. J Endod. 2002;28:(11):779-83.

Chen, CK, Wilson ME. Eikenella corrodens in human oral and non-oral infections: a review. J Periodontol. 1992;63:941-53.

Cogulu D, Uzel A, Önçag O, Aksoy SC, Eronat C. Detection of Enterococcus faecalis in Necrotic Teeth Root Canals by Culture and Polymerase Chain Reaction Methods. Eur J Dent. 2007;1(4):216-21.

Cogulu D, Uzel A, Önçag O, Eronat C. PCR-based identification of selected pathogens associated with endodontic infections in deciduous and permanent teeth. Oral Surg Oral Med Oral Pathol Oral Radiol Endod. 2008a;106(3):443-9.

Cogulu D, Uzel A, Önçag O, Aksoy C, Eronat C. Evaluation of Antibiotic Susceptibility of Enterococcus faecalis Isolated from deciduous and permanent tooth root canals. $J$ Hacettepe Faculty of Dentistry. 2008b;32(2):39-44.

Cohen MM, Joress SM, Calisti LP. Bacteriologic study of infected deciduous molars. Oral Surg Oral Med Oral Pathol. 1960;13:382-6.

Cooper PR, Takahashi Y, Graham LW, Simon S, Imazato S, Smith AJ. InflammationRegeneration Interplay in the Dentine-Pulp Complex. J Dent. 2010;38(9):687-97.

Conrads G, Gharbia SE, Gulabivala K, Lampert F, Shah HN. The use of a 16s rDNA directed PCR for the detection of endodontopathogenic bacteria. $J$ Endod. $1997 ; 23: 433-8$.

Cuoghi AO, Bertoz FA, de Mendonca MR, Santos EC. Loss of space and dental arch length after the loss of the lower first primary molar: a longitudinal study. The Journal of Clinical Pediatric Dentistry. 1998;22:117-20.

Doan N, Contreras A, Flynn J, Slots J, Chen C. Molecular Identification of Dialister pneumosintes in subgingival plaque of humans. J Clin Microbiol. 2000;38:3043-7.

Dunston B, Coll JA. A survey of primary tooth pulp therapy as taught in US dental schools and practiced by diplomates of the American Board Of Pediatric Dentistry. Pediatr Dent. 2008;30:42-8. 
Edwards S, Nord CE. Identification and characterization of micro-organisms isolated from infected primary teeth. J Int Assoc Dent Child. 1972;3(1):15-8.

Engstrom B, Frostell G. Experiences of Bacteriological Root Canal Control. Acta Odontol Scand. 1964;22:43-69.

Evans M, Davies JK, Sundqvist G, Figdor D. Mechanisms involved in the resistance of Enterococcus faecalis to calcium hydroxide. Int Endod J. 2002;35:221-8.

Fabricius L, Dahlén G, Holm SE, Möller ÅJ. Influence of combinations of oral bacteria on periapical tissues of monkeys. Scand J Dent Res. 1982;90:200-6.

Fabris AS, DiRienzo JM, Wïkstrom M, Mayer MP. Detection of cytolethal distending toxin activity and cdt genes in Actinobacillus actinomycetemcomitans isolates from geographically diverse populations. Oral Microbiol Immunol. 2002;17(4):231-8.

Fanning EA. The relationship of dental caries and root resorption of deciduous molars. Arch. oral Biol. 1962:7:595-601.

Faria G, Nelson-Filho P, de Freitas AC, Assed S, Ito IY. Antibacterial effect of root canal preparation and calcium hydroxide paste (Calen) intracanal dressing in primary teeth with apical periodontitis. J. Appl. Oral Sci. 2005;13(4):351-5.

Fouad, AF, Barry J, Caimano M, Clawson M, Zhu Q, Carver R, Hazlett K, Radolf JD. PCR-based identification of bacteria associated with endodontic infections. J Clin Microbiol. 2002;40(9):3223-31.

Gharbia SE, Haapasalo M, Shah H, Kotiranta A, Lounatmaa K, Pearce MA, Devine DA. Characterization of Prevotella intermedia and Prevotella nigrescens isolates from periodontic and endodontic infections. J Periodontol. 1994;65:56-61.

Godoy VL de. Distribuição de bactérias planctônicas, colônias bacterianas e biofilmes microbianos em dentes decíduos com pulpite e ou necrose pulpar. [tese (Doutorado em Odontopediatria)]. Bauru, SP: Faculdade de Odontologia de Bauru da Universidade de São Paulo; 1999.

Gomes BP, Pinheiro ET, Sousa EL, Jacinto RC, Zaia AA, Ferraz CC, de Souza-Filho FJ. Enterococcus faecalis in dental root canals detected by culture and by polymerase chain reaction analysis. Oral Surg Oral Med Oral Pathol Oral Radiol Endod. 2006;102(2):247-53. 
Gomes BC, Esteves CT, Palazzo IC, Darini AL, Felis GE, Sechi LA, Franco BD, De Martinis EC. Prevalence and characterization of Enterococcus spp. isolated from Brazilian foods. Food Microbiol. 2008;25(5):668-75.

Grenier, D. Collagen-bindi ng activity of Prevotella intermedia measured by a microtitre plate adherence assay. Microbiohgy. 1996;142:1537-41.

Gorski JP, Marks Jr. SC. Current concepts of the biology of tooth eruption. Crit Rev Oral Biol Med. 1992;3(3);185-206.

Hancock HH, Sigurdsson A, Trope M, Moiseiwitsch J. Bacteria isolated after unsuccessful endodontic treatment in a North American population. Oral Surg Oral Med Oral Pathol Oral Radiol Endod. 2001;91(5):579-86.

Harokopakis-Hajishengallis E. Physiologic root resorption in primary teeth: molecular and histological events. E J Oral Sci. 2007;49(1):1-12.

Hashioka K, Yamasaki M, Nakane A, Horiba N, Nakamura H. The relationship between clinical syntoms and anaerobic bacteria from infected root canals. J Endod. 1992;18(11):558-61.

Hobson P. Pulp treatment of deciduous teeth. Part 1 - Factors affecting diagnosis and treatment. Br Dent J. 1970;128:232-8.

Jacinto RC, Montagner F, Signoretti FGC, Almeida GC, Gomes BPFA. Frequency, microbial interactions, and antimicrobial susceptibility of Fusobacterium nucleatum and Fusobacterium necrophorum isolated from primary endodontic Infections. J Endod. 2008;34:1451-6.

Johnson EM, Flannagan SE, Sedgley CM. Coaggregation interactions between oral and endodontic Enterococcus faecalis and bacterial species isolated from persistent apical periodontitis. J Endod. 2006;32(10):946-50.

Kakehashi S, Stanley HR, Fitzgerard RJ. The effects of surgical exposures of dental pups in germ-free and conventional laboratory rats. Oral Surg. 1965;20:340-9.

Kantz WE, Henry CA. Incidence of Streptococcus mutans in root canals. J Dent Res. 1973;52(5):1163. 
Kayaoglu G, Ørstavik D. Virulence factors of Enterococcus faecalis: relationship to endodontic disease. Crit Rev Oral Biol Med. 2004;15:308-20.

Ke D, Picard FJ, Martineau F, Ménard C, Roy PH, Ouellette M, Bergeron MG. Development of a PCR assay for rapid detection of enterococci. J Clin Microbiol. $1999 ; 37: 3497-503$

Keudell K, Conte M, Fujimoto L, Ernest M, Berry HG. Microorganisms isolated from pulp chambers. J Endod. 1976;2(5):146-8.

Kerekes K, Olsen I. Similarities in the microfloras of root canals and deep periodontal pockets. Endod Dent Traumatol. 1990;6(1):1-5.

Kishen A, Sum C, Mathew S, Lim C. Influence of Irrigation regimens on the adherence of Enterococcus faecalis to root canal dentin. J Endod. 2008;34:850-4.

Lin LM, Pascon EA, Skribner J, Gängler P, Langeland K. Clinical, radiographic, and histologic study of endodontic treatment failures. Oral Surg Oral Med Oral Pathol. 1991;71(5):603-11.

Linde A. The extracellular matrix of the dental pulp and dentin. J Dent Res. 1985; 64:523-9.

MacDonald JB, Hare GC, Wood, AW. The bacteriologic status of the pulp chambers in intact teeth found to be nonvital following trauma. Oral Surg Oral Med Oral Pathol. 195710(3):318-22.

Marsh SJ, Largent MD. A bacteriological study of the pulp canals of infected primary molars. ASDC J Dent Child. 1967;34:460-9.

Metzger Z, Blasbalg J, Dotan M, Weiss El. Enhanced attachment of Porphyromonas gingivalis to human fibroblasts mediated by Fusobacterium nucleatum. $\mathrm{J}$ Endod. 2009;35:82-5.

Miller WD. An introduction to the study of the bacterio-pathology of the dental pulp. Dent. Cosmos. 1894;36(7):505-28. 
Mohammadi Z, Abbott PV. Antimicrobial substantivity of root canal irrigants and medicaments: a review. Aust Endod J. 2009;35(3):131-9.

Möller AJ. Microbiological examination of root canals and periapical tissues of human teeth. Methodological studies. Odontol Tidskr. 1966;74(5 Suppl):1-380.

Moore WE, Holdeman LV, Cato EP, Smibert RM, Burmeister JA, Palcanis KG, Ranney RR. Comparative bacteriology of juvenile periodontitis. Infect Immun. 1985; 48(2):507-19.

Morabito A, Defabianis P. A SEM investigation on pulpal-periodontal connections in primary teeth. ASDC J Dent Child. 1992;59:53-7.

Moss SJ, Addelston H, Goldsmith ED. Histologic Study of Pulpal Floor of deciduous molars. J Am Dent Assoc. 1965:70:372-9.

Nagaoka S, Miyazaki Y, Liu HJ, Iwamoto Y, Kitano M, Kawagoe M. Bacterial invasion into dentinal tubules of human vital and nonvital teeth. J Endod. 1995;21(2):70-3.

Nair PNR. Light and electron microscopic studies of root canal flora and periapical lesions. J. Endod. 1987;13(1):29-39.

Nair PN, Sjögren U, Krey G, Kahnberg KE, Sundqvist G. Intraradicular bacteria and fungi in root-filled, asymptomatic human teeth with therapy-resistant periapical lesions: a long-term light and electron microscopic follow-up study. J Endod. 1990: 16(12):580-8.

Naito Y, Gibbons RJ. Attachment of Bacteroides gingivalis to collagenous substrata. Dent Res. 1988;67(8):1075-80.

Nandakumar R, Mirchandani R, Fouad A. Primer sensitivity: can it influence the results in Enterococcus faecalis prevalence studies? Oral Surg Oral Med Oral Pathol Oral Radiol Endod. 2007;103:429-32.

Oguntebi BR. Dentine tubule infection and endodontic therapy implications. Int Endod J. 1994;27(4):218-22. 
Önçag O, Hoşgör M, Hilmioğlu S, Zekioğlu O, Eronat C, Burhanoğlu D. Comparison of antibacterial and toxic effects of various root canal irrigants. Int Endod J. 2003; 36(6):423-32.

Önçag O, Cogulu D, Uzel A. Efficacy of various intracanal medicaments against Enterococcus faecalis in primary teeth: an in vivo study. J Clin Pediatr Dent. 2006; 30(3):233-7.

Ozbek SM, Ozbek A, Erdogaan AS. Analysis of Enterococcus faecalis in samples from Turkish patients with primary endodontic infections and failed endodontic treatment by real-time PCR SYBR green method. J Appl Oral Sci. 2009;17(5):370-4.

Paster BJ, Olsen I, Ass JA, Dewhirst FE. The breadth of bacterial diversity in the human periodontal pocket and other oral sites. Periodontology 2000. 2006;42:80-87.

Pazelli LC, Freitas AC, Ito IY, Souza-Gugelmin MC, Medeiros AS, Nelson-Filho P. Prevalence of microorganisms in root canals of human deciduous teeth with necrotic pulp and chronic periapical lesions. Pesqui Odontol Bras. 2003;17(4):367-71.

Peciuliene V, Balciuniene I, Eriksen HM, Haapasalo M. Isolation of Enterococcus faecalis in previously root-filled canals in a Lithuanian population. J Endod. 2000; 26(10):593-5.

Peciuliene V, Reynaud AH, Balciuniene I, Haapasalo M. Isolation of yeasts and enteric bacteria in root-filled teeth with chronic apical periodontitis. Int Endod J. 2001; 34(6):429-34.

Pirani C, Bertacci A, Cavrini F, Foschi F, Acquaviva GL, Prati C, Sambri V. Recovery of Enterococcus faecalis in root canal lumen of patients with primary and secondary endodontic lesions. New Microbiol. 2008;Apr;31(2):235-40.

Pinheiro ET, Gomes BP, Ferraz CC, Sousa EL, Teixeira FB, Souza-Filho FJ. Microorganisms from canals of root-filled teeth with periapical lesions. Int Endod J. 2003;36:1-11.

Queiroz AM, Nelson-Filho P, Silva LA, Assed S, Silva RA, Ito IY. Antibacterial activity of root canal filling materials for primary teeth: zinc oxide and eugenol cement, Calen paste thickened with zinc oxide, Sealapex and EndoREZ. Braz Dent J. 2009; 20(4):290-6. 
Rayner JA, Southam JC. Pulp changes in deciduous teeth associated with deep carious dentine. J Dent. 1979;7(1):39-42

Reisine ST, Psoter W. Socioeconomic status and selected behavioral determinants as risk factors for dental caries. J Dent Educ. 2001;65:1009-16.

Reddy S, Ramakrishna Y. Evaluation of antimicrobial efficacy of various root canal filling materials used in primary teeth: A microbiological study. J Clin Pediatr Dent. 2007;31:193-98.

Reeves R, Stanley HR. The relationship of bacterial penetration and pulpal pathosis in carious teeth. Oral Surg Oral Med Oral Patho. 1966;22(1):59-65.

Rimondini L, Baroni C. Morphologic criteria for root canal treatment of primary molars undergoing resorption. Endod. dent. Traumat. 1995:11(3):136-41.

Rôças IN, Siqueira JF Jr, Andrade AF, Uzeda M. Oral treponemes in primary root canal infections as detected by nested PCR. Int Endod J. 2003;36(1):20-6.

Rôças IN, Siqueira JF Jr, Santos KR. Association of Enterococcus faecalis with different forms of periradicular diseases. J Endod. 2004;30(5):315-20.

Rôças IN, Siqueira JF Jr. Culture-Independent detection of Eikenella corrodens and Veillonella parvula in primary endodontic Infections. J Endod. 2006a;32:509-512.

Rôças IN, Siqueira JF Jr. Characterization of Dialister species in Infected root canals. J Endod. 2006b;32:1057-61.

Rôças IN, Siqueira JF Jr. Distribution of Porphyromonas gingivalis fimA genotypes in primary endodontic infections. Oral Surg Oral Med Oral Pathol Oral Radiol Endod. 2010;109(3):474-8.

Rocha CT, Rossi MA, Leonardo MR, Rocha LB, Nelson-Filho P, da Silva LAB. Biofilm on the apical region of roots in primary teeth with vital and necrotic pulps with or without radiographically evident apical pathosis. Int Endod J. 2008;41(8):664-9.

Ruviére DB, Leonardo MR, da Silva, LAB, Ito IY, Nelson-Filho P. Assessment of the microbiota in root canals of human primary teeth by checkerboard DNA-DNA hybridization. J Dent Child. 2007;74(2):118-23. 
Saito Y, Fujii R, Nakagawa K, Kuramitsu HK, Okuda K, Ishihara K. Stimulation of Fusobacterium nucleatum biofilm formation by Porphyromonas gingivalis. Oral Microbiol Immunol. 2008;23:1-6.

Sakai VT, Campos MR, Machado MA, Lauris JR, Greene AS, Santos CF. Prevalence of four putative periodontopathic bacteria in saliva of a group of Brazilian children with mixed dentition: 1-year longitudinal study. Int J Pediatr Dent. 2007;17(3):192-9.

Sato T, Hoshino E, Uematsu $\mathrm{H}$, Noda T. Predominant obligate anaerobes in necrotic pulps of human deciduous teeth. Microbial Ecology in Health Disease. 1993;6(6): 269-75.

Sedgley CM, Lennan SL, Appelbe OK. Survival of Enterococcus faecalis in root canals ex vivo.Int Endod J. 2005;38(10):735-42

Sedgley C, Buck G, Appelbe O. Prevalence of Enterococcus faecalis at multiple oral sites in endodontic patients using culture and PCR. J Endod. 2006;32:104-9.

Shovelton DS. The presence and distribution of microorganisms within non-vital teeth. Br Dent J. 1964;117(3):101-7.

Shovelton DS. A study of deep carious dentine. Int Dent J. 1968;18(2):392-405.

Silva LAB, Nelson-Filho P, Faria G, Souza-Gugelmin MCM, Ito IY. Bacterial profile in primary teeth with necrotic pulp and periapical lesions. Braz Dent J. 2006; 17:144-8.

Siqueira JF Jr, De Uzeda M, Fonseca ME. A scanning electron microscopic evaluation of in vitro dentinal tubules penetration by selected anaerobic bacteria. $J$ Endod. 1996:22(6):308-10.

Siqueira JF Jr, Rôças IN, Favieri A, Santos KRN. Detection of Treponema denticola in endodontic infections by $16 \mathrm{~S}$ rRNA gene-directed polymerase chain reaction. Oral Microbiol Immunol. 2000;15:335-337.

Siqueira JF Jr, Rôças IN, Oliveira JCM, Santos KRN. Detection of putative oral pathogens in acute periradicular abscesses by $16 \mathrm{~S}$ rDNA directed PCR. J Endod. $2001 ; 27: 164-7$. 
Siqueira JF Jr, Rôças IN, Lopes HP. Patterns of microbial colonization in primary root canal infections. Oral Surg Oral Med Oral Pathol Oral Radiol Endod. 2002; 93(2):174-8.

Siqueira JF Jr, Rôças IN. Treponema socranskii in primary endodontic Infections as detected by nested PCR. J Endod. 2003a;29(4):244-7.

Siqueira JF Jr, Rôças IN. Campylobacter gracilis and Campylobacter rectus in primary endodontic infections. Int Endod J. 2003b;36:174-180.

Siqueira JF Jr, Rôças IN. Polymerase chain reaction-based analysis of microorganisms associated with failed endodontic treatment. Oral Surg Oral Med Oral Pathol Oral Radiol Endod. 2004;97:85-94.

Siqueira JF Jr, Rôças IN. Clinical implications and microbiology of bacterial persistence after treatment procedures. J Endod. 2008:34(11):1291-1301.

Siqueira JF Jr, Rôças IN. Diversity of endodontic microbiota revisited. J Dent Re. 2009;88(11):969-81.

Sjögren U, Figdor D, Persson S, Sundqvist G. Influence of infection at the time of root filling on the outcome of endodontic treatment of teeth with apical periodontitis. Int Endod J. 1997;30:297-306.

Slots J, Ashimoto A, Flynn MJ, Li G, Chen C. Detection of putative periodontal pathogens in subgingival specimens by $16 \mathrm{~S}$ ribosomal DNA amplification with the polymerase chain reaction. Clin Infect Dis. 1995;20(Suppl 2):S304-7.

Sobrinho AP, Barros MH, Nicoli JR, Carvalho MA, Farias LM, Bambirra EA, Bahia MG, Vieira EC. Experimental root canal infections in conventional and germ-free mice. J Endod. 1998;24:405-8.

Sogin ML, Morrison HG, Huber JA, Welch DM, Huse SM, Neal PR, Arrieta JM, Herndl GJ. Microbial diversity in the deep sea and the underexplored rare biosphere. Proc Natl Acad Sci USA. 2006;103:12115-20.

Stuart CH, Schwartz SA, Beeson TJ, Owatz CB. Enterococcus faecalis: its role in root canal treatment failure and current concepts in retreatment. J Endod. 2006; $32(2): 93-8$. 
Sundqvist G, Johansson E, Sjögren U. Prevalence of black-pigmented Bacteroides species in root canal infections. J Endod. 1989;15:13-19.

Sundqvist G. Association between microbial species in dental root canal infections. Oral microbiol. Immunol. 1992;7:257-62.

Sundqvist G. Taxonomy, ecology, and pathogenicity of the root canal flora. Oral Surg Oral Med Oral Pathol. 1994;78:522-30.

Sundqvist G, Figdor D, Persson S, Sjögren U. Microbiologic analysis of teeth with failed endodontic treatment and the outcome of conservative re-treatment. Oral Surg Oral Med Oral Pathol. 1998;85:86-93.

Thilander B. Dentoalveolar development in subjects with normal occlusion. A longitudinal study between the ages of 5 and 31 years. Eur J Orthod. 2009;31(2): 109-20.

Thomas AM, Chandra S, Chandra S, Pandey RK. Elimination of infection in pulpectomized deciduous teeth: a short-term study using iodoform paste. J Endod. $1994 ; 20(5): 233-5$.

Tomazinho LF, Avila-Campos MJ. Detection of Porphyromonas gingivalis, Porphyromonas endodontalis, Prevotella intermedia, and Prevotella nigrescens in chronic endodontic infection. Oral Surg Oral Med Oral Pathol Oral Radiol Endod. 2007;103:285-8.

Tomić-Karović K, Jelinek E. Comparative study of the bacterial flora in the surroundings, the root canals and sockets of deciduous molars. Int Dent J. 1971; $21: 375-88$.

Toyoshima Y, Fukushima H, Inoue JI, Sasaki Y, Yamamoto K, Katao H, Ozaki K, Moritani Y, Saito T, Hieda T. A bacteriological study of periapical pathosis on deciduous teeth. Shoni Shikagaku Zasshi. 1988;26:49-58.

Tronstad L, Kreshtool D, Barnett, F. Microbiological monitoring and results of treatment of extraradicular endodontic infection. Endod Dent Traumat. 1990;6(3):129-36. 
van Winkelhoff AJ, Kippuw N, De Graaff J. Cross-inhibition between black-pigmented Bacteroides species. J Dent Res. 1987;66:1663-7.

van Winkelhoff AJ, van Steenbergen TJM, De Graaff J. Porphyromonas (Bacteroides) endodontalis: its role in endodontal infections. J Endod. 1992;18:431-4.

Vermot-Gaud M. Evidences and statistical studies on the incidence of pulpperiodontal canals of deciduous molars and their relation to interradicular septum infection. Rev Fr Odontostomatol. 1967;14(9):1487-504.

Vidana R, Sullivan A, Billström H, Ahlquist M, Lund B. Enterococcus faecalis infection in root canals - host-derived or exogenous source? Lett Appl Microbiol. 2011; 52(2):109-15.

Wang X, Yang P, Yu Y. The study of histopathology and bacteriology of coronal pulp tissue in deciduous teeth with deep dentin caries. Zhonghua Kou Qiang Yi Xue Za Zhi. 2000;35(5):365-7.

Wayman BE, Murata SM, Almeida RJ, Fowler CB. A bacteriological and histological evaluation of 58 periapical lesions. J. Endod. 1992;18(4):152-5.

Winkler TF $3^{\text {rd }}$, Mitchell DF, Healey HJ. Bacterial study of human periapical pathosis employing a modified Gram tissue stain Oral Surg Oral Med Oral Pathol. 1972;34(1):109-16.

Winter GB. Abscess formation in connexion with deciduous molar teeth. Arch Oral Biol. 1962;7:373-9.

Wittgow W, Sabiston CB. Microorganisms from pulpal chambers of intact teeth with necrotic pulps. J Endod. 1975;1(5):168-71.

Yang QB, Fan LN, Shi Q. Polymerase chain reaction-denaturing gradient gel electrophoresis, cloning, and sequence analysis of bacteria associated with acute periapical abscesses in children. J Endod. 2010;36(2):218-23. 


\title{
ANEXO - Termo de Consentimento e Livre Esclarecimento
}

\author{
Universidade de São Paulo \\ Instituto de Ciências Biomédicas
}

TERMO DE CONSENTIMENTO LIVRE E ESCLARECIDO

(menores de 18 anos)

ESTUDO: "Análise molecular de microrganismos presentes nas infecções

endodônticas de dentes decíduos."

Seu filho está sendo convidado a participar do presente estudo. O documento abaixo contém todas as informações necessárias sobre a pesquisa que estamos fazendo. Leia atentamente. Caso tenha dúvidas, teremos prazer em esclarecê-las. Se concordar, o documento será assinado e só então daremos início ao estudo. Sua colaboração será muito importante para nós. Mas, se quiser desistir a qualquer momento, isto não causará nenhum prejuízo, nem a você, nem ao(à) seu (sua) fúho(a).

Eu $R G$ abaixo assinado (a), concordo de livre e espontânea vontade que meu(minha) filho(a) nascido(a) em _ _ _ _ _ seja voluntário do presente estudo. Declaro que obtive todas as informações necessárias e que todas as minhas dúvidas foram esclarecidas. Estou ciente de que:

I) O estudo é necessário para que se possa descobrir as possíveis causas e Vou o tratamento, se apropriado, de doenças causadas por microrganismos presentes nas infecções das raízes de dentes decíduos.

II) Serão feitas coletas utilizando cones de papel absorvente ou instrumentos endodônticos estéreis, que serão colocados por um minuto no conduto radicular do dente (canal), e fistula gengival (inflamação) quando presente.

III) Estas coletas serão feitas apenas para este estudo, sendo indolor, sem nenhum desconforto para criança.

IV) A participação neste estudo não tem fins terapêuticos e será sem custo algum.

V) Tenho a liberdade de desistir ou interromper a colaboração neste, estudo no momento em que desejar, sem necessidade de dar qualquer explicação;

VI) A desistência não causará nenhum prejuízo a mim, nem (a) meu (minha) filho(a), nem interferirá no atendimento ou tratamento odontológico a que ele(ela) estiver sendo submetido; 
VII) Os resultados obtidos durante este estudo serão mantidos em sigilo, mas concordo em que sejam divulgados em publicações científicas, desde que nem o meu nome, nem o de meu filho sejam mencionados;

VIII) Caso eu deseje, poderei tomar conhecimento dos resultados ao final deste estudo;

IX) Poderei contatar a Secretaria da Comissão de Ética em Pesquisa com Seres Humanos - ICB/USP -, no Fone (OxxIl) 3091.7733 ou (0xx27) 3322-4236 para recursos ou reclamações em relação ao presente estudo.

OBS: Assinalar abaixo com (x):

( ) Desejo conhecer os resultados desta pesquisa.

( ) Não desejo conhecer os resultados desta pesquisa.

Vitória, de de 20

( ) Paciente / ( ) Responsável 